\title{
K PROBLEMATIKE DATOVANIA VÝVOJOVÝCH FÁZ URBANOVEJ VEŽE V KOŠICIACH
}

\author{
JÁN KRCHO - RASTISLAV RUSNÁK
}

\begin{abstract}
Abstrakt: Príspevok reaguje na výsledky zatial' posledného stavebno-historického výskumu Urbanovej veže v Košiciach, ktorá je zvonicou farského kostola, Dómu sv. Alžbety, a ktorá je najmä v povojnovej literatúre datovaná do poslednej štvrtiny 14. storočia. Nové zistenia architektonického výskumu dopĺn̆ajú jednak výsledky dendrochronologického výskumu a jednak rozbor výsledkov dosial' jedinej archeologickej sondy umiestnenej v exteriéri veže na styku s jej murivom. Vyhodnotenie všetkých spomenutých výskumov vedie $k$ záveru, že tradičné povojnové datovanie stavby bude potrebné prehodnotit' a stavbu veže posunút' až na začiatok 17. storočia. Príspevok zároveň ponúka prehl'ad literatúry a prameňov o Urbanovej veži, vrátane staršej, predvojnovej literatúry, ktorá vo väčšine, naopak, podporuje novoveké datovanie stavby.
\end{abstract}

Kl'účové slová: Košice - Urbanova veža - zvonica-datovanie - renesancia.

\section{Dating of the Development Phases of the Urbanova Veža Tower, Košice}

Abstract: This contribution assesses the results of the latest building and historical research into Urbanova veža (Urban Tower) in Košice, the bell tower of the parish Church of St. Elisabeth. The tower is dated, especially in post-war literature, to the last quarter of the 14th century. New findings concerning architectural research are supplemented with the results of dendrochronological research and with the analysis of the results of the only archaeological probe so far, on the outside of the tower, on the masonry surface. The research results indicate that the post-war dating of the construction will have to be reassessed and the construction of the tower will have to be shifted to the early 17th century. At the same time, the article offers an overview of specialist literature and written sources devoted to Urbanova veža including earlier, prewar literature that, in contrast, supports the modern-age dating of the building.

Key words: Košice - Urbanova veža - bell tower - dating - renaissance.

Urbanova veža je masívna, štvorpodlažná stavba v centre historického jadra Košíc, postavená ako zvonica Dómu sv. Alžbety, hlavného farského kostola Košíc. V doterajšej literatúre prevládajú dva názory na datovanie jej výstavby. Starší historici datujú výstavbu celej Urbanovej veže do roku 1628 alebo 1629, novšie pramene uvažujú o nejakom (často bližšie neurčenom) stredovekom základe, ktorý bol v roku 1628 iba upravený. Po požiari v roku 1968 prevláda novšie datovanie, toto datovanie preberajú aj niektoré vel'ké syntézy dejín umenia na Slovensku (Urbanová 2009, 249, 704).

Z prvej skupiny historikov, ktorí výstavbu veže datujú do roku 1628: József Tutkó, János Sziklai a Samu Borovszky, Lajos Kemény, György Kerekes, Vojtech (Béla) Wick.

József Tutkó píše o stavbe veže ako o udalosti roka 1628. Vežu postavili pre zvon, ktorý sa nedal umiestnit' vo veži kostola. Svedčí o tom aj to, že pod zvon, ktorý bol nejaký čas v budove mestskej rady, ukryli telo mŕtveho Bocskayovho vojvodcu Blažeja Lipaya, zavraždeného v roku 1605 (Korponay 1866-1870, 31). V tom čase bol teda zvon mimo užívania: „E harang a sz. Erzsébet egyház egyik tornyába sem illesztethetettel, hanem azon kívül, az egykori tanács epületében, hol öntetett vala, egyszersmind helyt foglala is. Bizonyitja ezt azon esemény; midön Bocskay fövezére Lipay Balázs, a már annak helyén emlitett időben, megöletett, hullája ezen harang alá rejtetett, s mi arra mutat, hogy a nagy harang akkorában használaton kivül vala. Ez évben a városi tanács annak részére nagytornyot épittetett, s a harang bele is helyeztetett." (Tutkó 1861, 138-140) Podl'a monografie Abovskej župy vežu postavili začiatkom 16. storočia pre zvon Urban, lebo ten sa kvôli svojim rozmerom nedal umiestnit' vo veži farského kostola: „A dómtól északra néhány méternyire a XVI. század elején épült Orhán-torony, hatalmas, faragott köszegélyes falaival... Ezt kizárólag a Szt-Erzsébet templom számára öntött nagy harangnak emelték, mert azt terjedelme miatt nem helyezhettékel a dóm tornyában." (Sziklay-Borovszky 1896, 18) József Mihalik tvrdí, že vežu postavili v roku 1628: „Az Orbán-torony, 1628-ban épült azon 
nagy harang elhelyezésére, mely 1557-ben, a mégelözö évben Kassán dúlt tüzvészben megolvadt harangok megmaradt részeiböl öntetett lllenfeld Ferencz kassai mester által. A kapu fölött Kassa város czimere s egy felirat, az ajtó félkörü nyilasában csinos kovácsolt rácsmü foglal helyet.“ $(1897,43)$

Ďalšie podrobnosti o výstavbe veže uvádza košický archivár Lajos Kemény. Podl’a Keménya bol architektom veže Martin Lindner, prešovský občan (podl’a matriky prijatých za občanov mesta Prešov: Ao 162626 January Martinus Lindner architector moravus; ŠOBA Prešov, inv. č. 275), stavitel' Gabriela Bethlena, architekt jeho kniežacieho paláca v Gyulafehérvári (dnes Alba Julia). Prvé zmienky o výstavbe veže sa objavujú v štatútoch mesta z roku 1627, podl'a ktorých Adam Hellensperger zanechal závet a želal si určitú sumu použit' na výstavbu veže. Podl'a štatútu z roku 1628 mesto opät' súri výstavbu veže a podl’a listu Mateja Szikszayiho z 2. apríla 1628 kavečanskí poddaní nemôžu jednat' o pálení vápna na stavbu domu jeho výsosti (Gabriela Bethlena), kým ho na výstavbu veže nepripravia dostatok. V tom istom roku 28. augusta už meškajú kamenárske práce, lebo jeden z kamenárov veže pracuje v Levoči, druhý v Makovici (AMK, H). Podl’a zápisnice z 1. februára 1629 cech kováčov požaduje zaplatenie želiez, ktoré vyrobili pre vežu. V liste z 5. januára 1629 sa ponúka Martin Lindner, prešovský občan a stavebný majster jeho výsosti, že vežu postaví, tak ako postavil podobnú vežu v Gyulafehérvári (Alba Julia) a v Prešove. Podl’a d’alšieho záznamu z roku 1629 murárske a tesárske práce na veži v júni, resp. v septembri, prebiehajú, ale s meškaním. Podl’a Keménya nápisy nad portálom svedčia o začiatku, nie o dokončení prác na veži. Kemény sa prvý vyjadruje k problému gotického tvaru okien poschodia zvonov, podl'a neho sa do veže dostali ako druhotné prvky po požiari farského kostola (1556) alebo Kostola Sv. Leonarda (1566; Kemény 1901/1905, 9, 10). V inej štúdii Kemény publikuje zmluvu mesta na nový krov veže s tesárom Antonom Aranyossym z 31. mája 1754: Die 18 Junii. Accorda civitatis cum molitor e molae superioris Antonio Aranyossy respectu neoerigendi tecti turris rubrae in conformitate delineationiss.

1. Assummit molitor totum laboorem in se una cum sociis, operariis et manualistis per conducenandis et pesovendis.

\section{Assummit pariformiter turis decolorationem}

3. Assumit, insuper nit insuper intrinsecorum turrisusdem reparationem, uti sünt gradus, podia et reliqua circa magnam campanam substacula.

Econverso 4. Civitas permittit molitori pro toto hoc labore Rh. fl. quadringentas.

5. Praestabit miversa materialia et eorum convectionem sub turrim.

6. Praestabit demum colores et oleum pro decoloratione turris (1916, 224, 225). Uvádza aj potvrdenie o zaplatení 33 rýnskych zlatiek a 24 grajciarov Štefanovi Vörösovi za namalovanie veže, ktoré mu mal vyplatit' Anton Aranyossy z celkovej sumy 400 rýnskych zlatiek, určenej na opravu veže. Podl'a rozhodnutia z 10. novembra 1755 mu nakoniec zaplatili 50 rýnskych zlatiek a dali mu dve prasatá: „Antonii Aranyossy molitoris sumptis in justam considerationem circa erectionem rubrae turris praestitis fatigiis pro codigna eorum remuneratione eidem conventionetenus obventos salva venia duo setigeri et ultra conventionem ad huc rh. $f$ l. 50 ea lege resolvunt ur, utomnia ea, quae circa attactam turrim reparanda restant, ante levationem resolutae hujus mercedis reparet et ad perfectum statum deducere tenetur." (1916, 224, 225) Kornél Divald spája výstavbu veže s dátumom odliatia zvonu. Podl’a neho vežu postavili v druhej polovici 16. storočia a vtedy ju aj vyzdobili sgrafitami (Divald 1899, 223). Takmer na tie isté pramene ako Kemény sa odvoláva aj György Kerekes. V životopise košického starostu Štefana Almássyho uvádza jeho nariadenie z roku 1628, podl'a ktorého sa peniaze z pozostalosti Adama Hellenspergera určené na výstavbu Urbanovej veže nesmeli použit' na iné účely a nariad'uje čím skôr dokončit' stavbu veže (Kerekes 1902, 96). V inej práci uvádza, že Urbanova veža bola postavená v čase sudcovstva Štefana Almássyho v resesančnom štýle. Jej stavitel’om bol Martin „Lidtner", pôvodom z Prešova, stavebný majster Gabriela Bethlena, ktorý pracoval aj na jeho paláci v Gyulafehérvári (Alba Julia). Veža je vlastne zvonica, do ktorej umiestnili zvon Urban 
odliaty zo zvyškov viacerých zvonov, po požiari v roku 1556, pretože sa pre vel'ké rozmery nedal umiestnit' ani do jednej z veží dómu (Kerekes 1943, 186).

Keményove a Kerekesove údaje preberá a dopĺn̆a Vojtech Wick, ktorý o Urbanovej veži píše vo viacerých dielach (Wick 1928; 1941). Zvlášt' dôležité sú jeho zoznamy náhrobkov, pri niektorých sú Wickove opisy jediné, podl'a čoho sa dajú značne zvetrané náhrobky ešte dnes identifikovat' (1928, 15-18; 1928a, 173-174; 1933, 49-117). Vojtech Wick prichádza s tézou, podla ktorej názov Červenej veže pochádza od predchodcu Urbanovej veže, pod ktorým bola staršia zvonica spomínaná aj v písomných prameňoch mesta. V roku 1580 obchodník Gaspar Trollus, od „cintorína pri zvonici“" vystrelil zo zbrane gul'ku, ktorou zabil Samuela Borsosa: „1580. Casper Trollus mercator, qui globo sclupeti ad cimitererium prope campanile emisso interfecerat." (AMK, Prot.) Dňa 13. júna 1624 István Izdeczy prosí magistrát, aby pred pohrebom jeho synáčika upravil krytinu pri „Červenej veži“ a polovicu malej klenby (?) epitáfia (,az fiacskája temetésse felett csináltasson fel hajazatott a veres toronynál és egy kis boltozatot a felibe az epitaphiumot"; Wick 1928, 6). V neskorších prácach zdôrazňuje už iba to, že Urbanovu vežu, nazývanú predtým Červená veža, postavil dvorný architekt Gabriela Bethlena Martin Lindner v roku 1628 a že o príbehu veže podrobne pojednávajú verše latinského dichtikonu (nad jej vstupom): „Extructae cupiens spectator noscere turris authores, flexo lumine percipies. Namque senatorum claro cum iudiceclarus. Quempenes impérium tunc fuit, ordo micat. Nulla superstitio mea forsitam area fatiget sed verus verae religionis amor. O benedicta trias! Tanto, fac, dogmata, plausu, ut mea per coelum verbera Sacratonent. Anno Domini MDCXXVIII.“ (Ak chceš poznat' ó divák zhotovitel'ov tejto postavenej veže, pohl'adom sem sa to dozvieš. Lebo tu sa skvie richtár a senátorov slávny rad, ktorí mali vtedy v rukách moc. Ó požehnaná trojica! Daj nech sa zapáčia tvoje učenia, nech cez nebesá znie sväté slovo môjho úderu. Roku pána 1628.) Na kamennej platni pod erbom mesta je zoznam mien vtedajšieho richtára a senátorov: „Judex Stephanus Almásy. Joan: Langh, Vale: Konczik, Vences: Swertel, And: Demek, Nic: Keözegy, Micha: Was, Gre: Miskolczy, Georg: Ruffer, Pet: Molnár, Georg: Fraidenberger, Joan: Debreczeny, Fran: Traganer.“ (Wick 1941, 367-370) Veža však zostala „Červenou“ i začiatkom druhej polovice 17. storočia, ako to nepriamo spomína lakonická zmienka z Uhorského Simplicissima: „Ked’ sa potom vracajú z cvičenia v poriadku do mesta, musia ešte dvakrát vypálit' na múriku cintorína, ktorý sa podobá ochrannej, poprsnej hradbe a bubenik robi pri tomto výstupe strašlivý rachot, aby tým ešte strel'bu zosilnil. Kostolná veža je pokrytá med'ou, zvonica je však omietnutá čistým vápnom, do ktorého je primiešané víno." (Uhorský Simplicissimus 1975, 122) Autor cestopisu Daniel Speer strávil na území dnešného Slovenska roky 1654-1660.

Ďalší významný príspevok k problému stavebného vývoja Urbanovej veže prináša Sándor Mihalik. Sumarizuje dovtedajšiu literatúru s datovaním výstavby do roku 1628, s neurčitým, archívne uvádzaným predchodcom veže (ktorého spomína aj Wick v roku 1580), ale súčasne upozorňuje na veduty mesta $\mathrm{z}$ badenského archívu (obr. 1, 2), na ktorých je zobrazená Urbanova veža v dvoch pohl'adoch so strechou s fialami. Predchodca veže, staršia zvonica, podl'a Mihalika na Houfnagelovej rytine už nie je zobrazená (podl’a nášho názoru sa ako vrchol veže dá identifikovat' trojuholník prečnievajúci nad hrebeň strechy Kostola sv. Alžbety; obr. 3). Sándor Mihalik pomerne podrobne popisuje aj d’alšie úpravy veže v roku 1912 a v roku 1943 (1943, 14-17). ${ }^{1}$

Vývoj Urbanovej veže sa dá čiastočne sledovat' aj na zachovaných historických mapách, vedutách a plánoch. Na plánoch mesta zo 16. storočia a na plánoch zobrazujúcich stav mesta v 16. storočí Urbanova veža nie je zobrazená: Casovia - Befestingugplan von Kaschau (ÖNB, cod. 8609), Cassovia DS (Daniel Speckle 1536-1589) z roku 1577 (Landesarchiv Karlsruhe HfK XVII, fol. 16), Cascha N:37 (Kisari Balla 1996, 52, 98) a Casovia (Landesarchiv Karlsruhe HfK XV, fol. 47). Najstarší plán, na ktorom je zobrazená veža, je až z roku 1685: Plan de la Ville de Caschau (Landesarchiv Karlsruhe HfK VI, fol. 39; obr. 4). Na rytine Georga Hoefnagela (z tých zobrazení, ktoré sú viditel’ne zhotovené na základe autopsie) je podl’a kresby Egidiusa van der Ryea nad strechou Kostola svätej Alžbety (obr. 3) nakreslený vrchol ihlanu (veže?) okolo roku

1 Práca napísaná v mad’arčine obsahuje i nie vel'mi presne preloženú slovenskú verziu. Uvedené údaje sa v nej nachádzajú na stranách 32-34. 


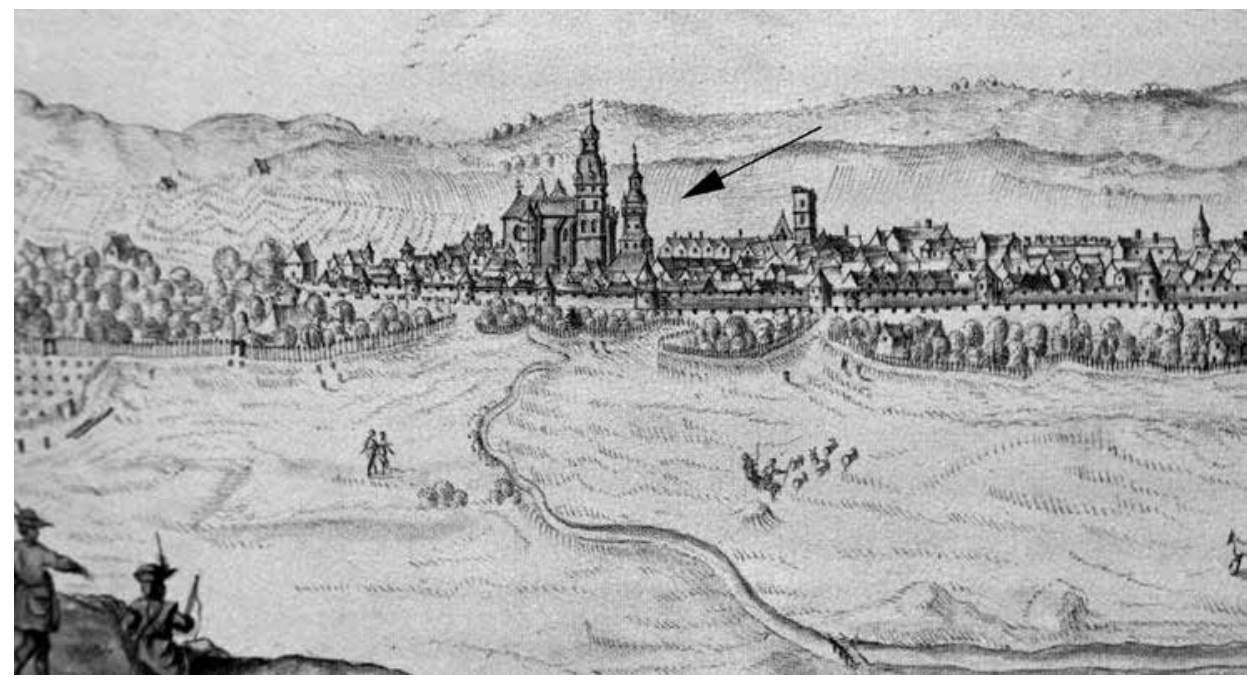

Obr. 1. Košice, Urbanova veža. Čast' pohl’adu z východnej strany s vyznačenou vežou, kresba Johannesa Ledentua okolo roku 1639, Vienna, Österreichische Nationalbibliothek, cod. 8623, fol. 23.

Abb. 1. Košice, Urban-Turm. Teilansicht von Osten mit gekennzeichnetem Turm, Zeichnung von Johannes Ledentu um 1639, Wien, Österreichische Nationalbibliothek, cod. 8623, fol. 23.

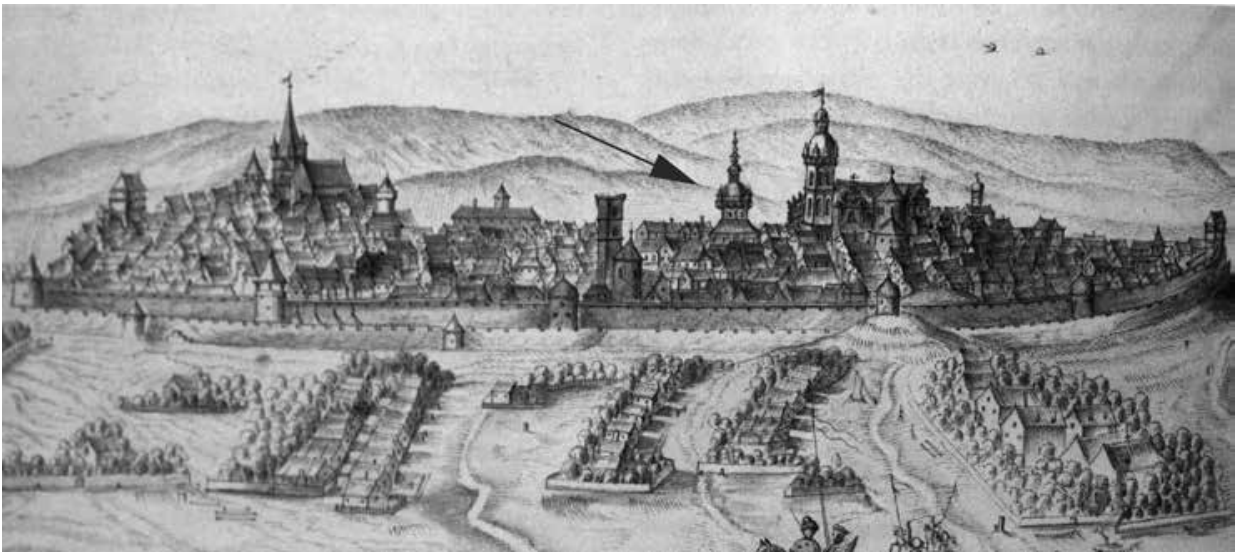

Obr. 2. Košice, Urbanova veža. Čast’ pohl’adu zo západnej strany s vyznačenou vežou, kresba Johannesa Ledentua okolo roku 1639, Vienna, Österreichische Nationalbibliothek, cod. 8623, fol. 24.

Abb. 2. Košice, Urban-Turm. Teilansicht von Westen mit gekennzeichnetem Turm, Zeichnung von Johannes Ledentu um 1639, Wien, Österreichische Nationalbibliothek, cod. 8623, fol. 24.

1600, s istotou pred rokom 1617 (Civitates Orbis Terrarum 1617, plate 31). V prípade tohto zobrazenia ide o jeden z mála ako tak hodnoverných dokladov, na základe ktorých je možné uvažovat’ o tom, že už vtedy tu stála Urbanova veža alebo nejaký iný predchodca veže. Na lepte Wilhelma Schäffera-Dilicha (1571-1650) zo začiatku 17. storočia (a ani na zobrazeniach podl'a tohoto leptu: Wilhelm Peter Zimmermann, a Johan A. Thelot a Georg A. Wohlfgang; Groško 1980, 43-45) Urbanova veža nie je zobrazená. Na vedutách zo 17. storočia, kresbách Johanna Ledentua okolo roku 1639 (ÖNB, cod. 8623) a na takmer identických kresbách Košíc (dva pohlady a pôdorys mesta) z Karlsruhe (Landesarchiv Karlsruhe HfK XIII, fol. 50-52) je na vedutách veža zobrazená s členitou, viacúrovňovou cibulovitou helmicou aj s nárožnými vežičkami (obr. 1, 2). 


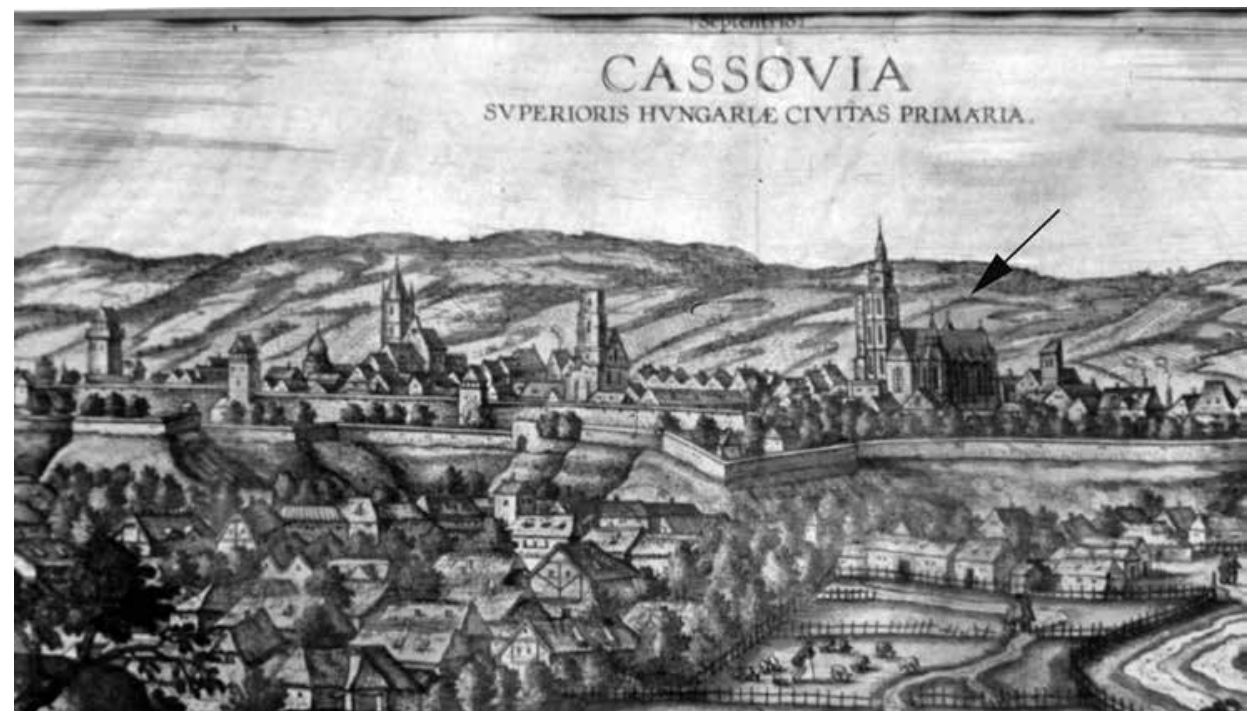

Obr. 3. Košice, Urbanova veža. Čast' rytiny so zakreslenou vežou (?), Rytina Georga Hoefnagela z roku 1617, Braun \& Hogenberg, Civitates Orbis Terrarum, vol. 6, plate 31.

Abb. 3. Košice, Urban-Turm. Teil eines Kupferstiches mit eingezeichnetem Turm (?), Kupferstich von Georg Hoefnagel aus dem Jahr 1617, Braun \& Hogenberg, Civitates Orbis Terrarum, Bd. 6, Tafel 31.

Urbanova veža sa neuvádza ani v podrobnom popise mesta „Relation“ z roku 1603. V súpise uvádzaná Červená veža (neskôr hlavne v 18. storočí takto nazývali aj Urbanovu vežu, pozri d’alej) je jednoznačne veža cechu mäsiarov: „No 69. Der Rothe Thurn, welcher der Fleischhackerzechzugehörig. Darauf ist scharfen Tindl darungter das unntter Tailain Gewelb, darinnen Ihren Majestäts Pulver gehalten wirdt. An diesem ist der Aufgang der Stigen zu verbessern und rain zu halten." (Relatio 1603, No. 69) Podl'a súpisu to bola veža opevnenia, vnútorného pásu hradieb, ktorá stála na konci dnešnej Poštovej ulice (Krcho 1992, 200, 204, 213). Na grafikách z 18. storočia je veža zobrazovaná ešte s ochodzou pod cibul'ovitou helmicou nad korunnou rímsou, ale už aj s kvádrovou rustikou okolo rámov okien a na nárožiach. Najpresnejšie je zobrazená ako: „3. Rubra Turris“ na pláne: Delineatio lib. reaeq. civit. Cassoviensis cujus mensura in locu. scalae in tabellis adjungitur (obr. 5) od Antona Svajcera (podla archívu okolo roku 1780, ale pravdepodobnejšie pred požiarom v roku 1775; MOL, Térképtár: S 11 No 0490:1). Na vedutách, mal'bách a už aj fotografiách z 19. storočia je veža zobrazovaná s plochou stanovou strechou, ktorá sa zachovala do čias požiaru v roku 1966. Okolo polovice storočia aj s prístavbami drobných obchodov, ktoré zbúrali v roku 1880 (obr. 6; AMK Mag.). Vežu s pristavanými obchodmi zobrazujú mal'by Jakuba Alta z roku 1839 (Groško 1980, 52, 53), kresba Viktora Myskovszkého (Forster Központ, 5187) a čiastočne aj niektoré fotografie. Do roku 1912 bola veža bez prístavieb. Jej d’alšiu úpravu, ked' bola pristavaná ochodza, čiastočne s obchodmi, záchodom a prezentovali sa kamenné náhrobky, nájdené počas prác v dóme, navrhol Otto Sztehlo v roku 1909, práce boli dokončené v roku 1912 (obr. 7). Ďalšie úpravy ochodze dokončili v roku 1947 (obr. 8).

Po požiari 3. decembra 1966 dochádza k zmene pohladu na Urbanovu vežu. Väčšina bádatel'ov preferuje datovanie veže do stredoveku s úpravami v roku 1628. Snád' prvýkrát sa tento názor objavuje v Súpise pamiatok na Slovensku (SPS 1968, 99). ${ }^{2}$ Najd’alej zachádza Ondrej R. Halaga, ktorý jej spodné časti kladie do predkolonizačného obdobia, teda pred rok 1242-1249 (Halaga 1992, 116-120).

2 Súpis d’alej uvádza 31 náhrobkov a štyri nezistené (čo zodpovedá dnešnému počtu okrem dvoch viditel’ne dodatočne osadených, pozri d'alej súpis chránených prvkov). 


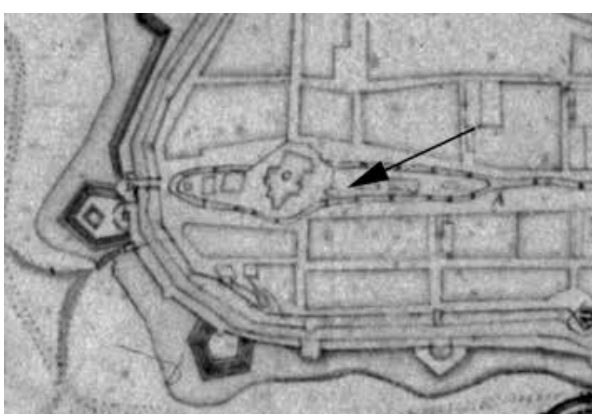

Obr. 4. Košice, Urbanova veža. Čast' plánu so zakreslenou vežou, Plan de la Ville de Caschau, z roku 1685, Baden-Württenberg Generallandesarchiv Karlsruhe HfK VI, fol. 39.

Abb. 4. Košice, Urban-Turm. Teil einer Planskizze mit eingezeichnetem Turm, Plan de la Ville de Caschau aus dem Jahr 1685, Baden-Württenberg Generallandesarchiv Karlsruhe HfK VI, fol. 39.

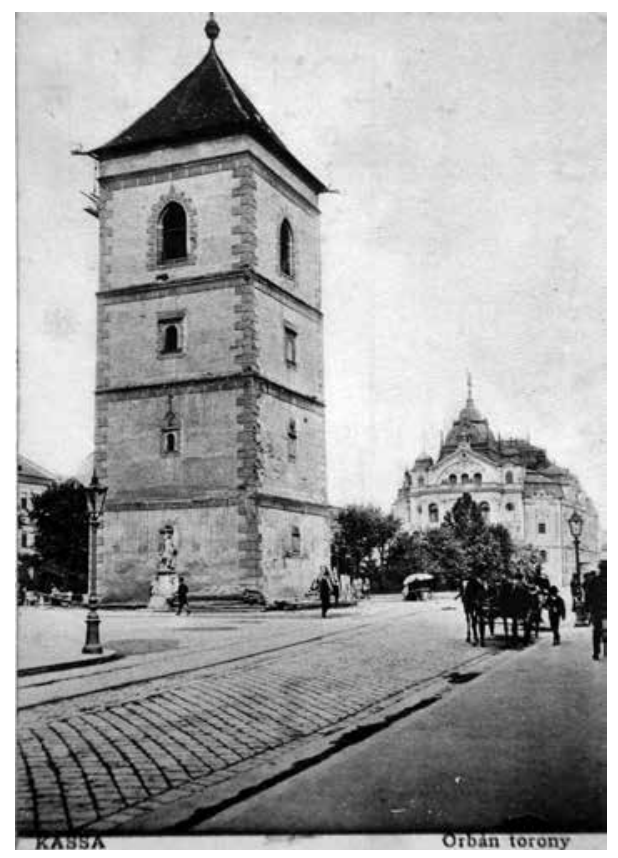

Obr. 6. Košice, Urbanova veža. Fotografia Urbanovej veže z juhovýchodu (pohl'adnica, 1880-1912), Forster Központ, Budapest - fotótár, 569.

Abb. 6. Košice, Urban-Turm. Fotografie des Urban-Turms von Südosten (Ansichtskarte, 1880-1912), Forster Központ, Budapest - Fotótár, 569. realizovaný hlavne nedeštruktívnymi metódami, ale aj sondážou. Celkovo bolo zhotovených 34 sond, ktoré v roku 2016 Tomáš Kyncl doplnil d’alšími dvomi sondami v úrovni horných „gotických“ zvukových okien pre dendrochronologické datovanie. Pri výskume sme vychádzali z pre-

Obr. 5. Košice, Urbanova veža. Čast' pohl'adu na mesto na pláne Delineatio lib. reaeq. civit. Cassoviensis... s vyznačenou vežou, plán od Antona Svajcera (podl’a archívu okolo roku 1780, pravdepodobne pred požiarom v roku 1775), MOL, Térképtár: S 11 No 0490:1.

Abb. 5. Košice, Urban-Turm. Teilansicht der Stadt auf dem Plan Delineatio lib. reaeq. civit. Cassoviensis... mit eingezeichnetem Turm, Plan von Anton Svajcer (laut Archiv um das Jahr 1780, wahrscheinlich vor dem Brand im Jahr 1775), MOL, Térképtár: S 11 No 0490:1.

Najvýznamnejší a najdôkladnejšie spracovaný príspevok k poznaniu stavebného vývoja veže bol doposial' pamiatkový výskum Evy Križanovej a Vojtecha Fifíka po požiari z roku 1968, na ktorom spolupracovala aj Mária Spoločníková (reštaurátorský výskum; 1968). Výsledky výskumu boli aj publikované (Križanová 1971). Na základe gotických foriem okien na poschodí zvonovej stolice, ktoré majú podobnú profiláciu ako okná Michalskej kaplnky, datuje vznik celej zvonice do posledných dvoch desat'ročí 14. storočia (Križanová 1971, 205). Stavba veže podl'a nej súvisela s prestavbou farského kostola, resp. jej predchádzala. Názory Evy Križanovej ale neboli úplne jednoznačne prijaté ani v odborných kruhoch. Ivan Kuhn datuje výstavbu Urbanovej veže do roku 1628 a za renesančné považuje aj všetky spišské zvonice postavené v 16. a 17. storočí $(1982,52)$. Norma Urbanová Križanovej datovanie niekde obchádza (2003, 71-86, 277-284), inokedy ho prijíma (2009, 249, 704). Do stredoveku ju datuje O. R. Halaga (1992, 116-120) a po ňom už takmer každý, okrem iných aj Tim Juckes $(2009,29)$.

V rokoch 2014-2015 prebehol stavebno-historický výskum veže (Krcho 2015) v súvislosti s jej plánovanou obnovou. Výskum bol 


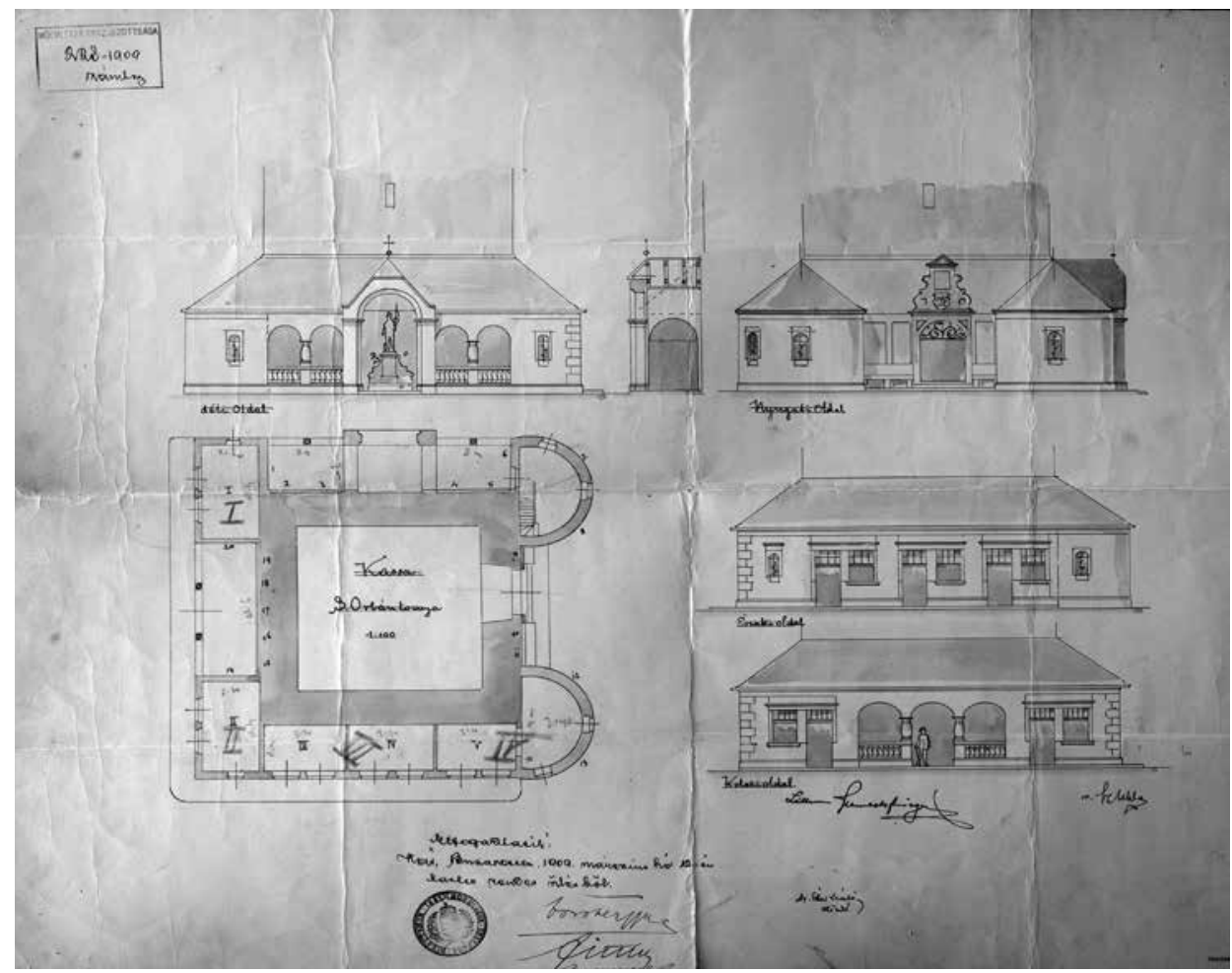

Obr. 7. Košice, Urbanova veža. Plán úpravy veže, Otto Sztehlo, signované 1908 (?), schválené 12. marca 1909, AMK, Technický archív mesta, Urbanova veža.

Abb. 7. Košice, Urban-Turm. Plan für den Umbau des Turms, Otto Sztehlo, signiert 1908 (?), genehmigt am 12. März 1909, AMK, Technisches Archiv der Stadt, Urban-Turm.

mís posledného výskumu (Križanová-Fifík 1968) a snažili sme sa presne identifikovat' staršie stredoveké časti veže. Okrem výsledkov stavebno-historického výskumu aj vo svetle širšieho umeleckohistorického výskumu renesančného umenia, archeologického výskumu v okolí veže a v neposlednom rade aj dendrochronologickej analýzy sme dospeli k názoru, že datovanie veže do 14. storočia (alebo dokonca do 13. storočia) je neudržatel'né.

Doteraz jediné archeologické práce v bezprostrednom susedstve Urbanovej veže prebehli v roku 2006, počas archeologického výskumu námestia medzi severnou stranou Dómu sv. Alžbety a parkom (obr. 9). Výsledky archeologického výskumu, ktorý realizoval AÚ SAV VPS Košice, boli čiastočne publikované v článku zameranom na nálezy stredovekých drevených stavebných konštrukcií (Henning-Rusnák 2008, 151-156), d’alší príspevok spracováva vrcholnostredovekú keramiku z výskumu (Rusnák v tlači). Stručne, informatívne vyhodnotený bol i stavebný vývoj námestia okolo dómu, zohl’adňujúci výsledky archeologických výskumov (Rusnák 2013). Viaceré vtedy publikované závery bude teraz nutné prehodnotit'. Realizovaných bolo celkove pätnást' sond, jedna z nich - sonda 10/06 - bola situovaná priamo k západnej stene veže. Možnosti umiestnenia exteriérovej archeologickej sondy v dotyku s murivom veže boli viac-menej pevne dané. Krytá arkádová ochodza, pristavaná v rokoch 1909-1910 (Gašpar 2011, 41), obopínajúca celú severnú, východnú a južnú stenu a čiastočne i západnú stenu veže a funkčný vstup v západnom priečelí stanovili umiestnenie sondy medzi vstupný portál z juhu a murivo arkádovej ochodze zo severu ako jediné možné. Ciel’om realizácie sondy bolo zdokumentovat' miesto a formu napojenia cintorínskeho múru na murivo Urbanovej veže, zistit' sled vrstiev 


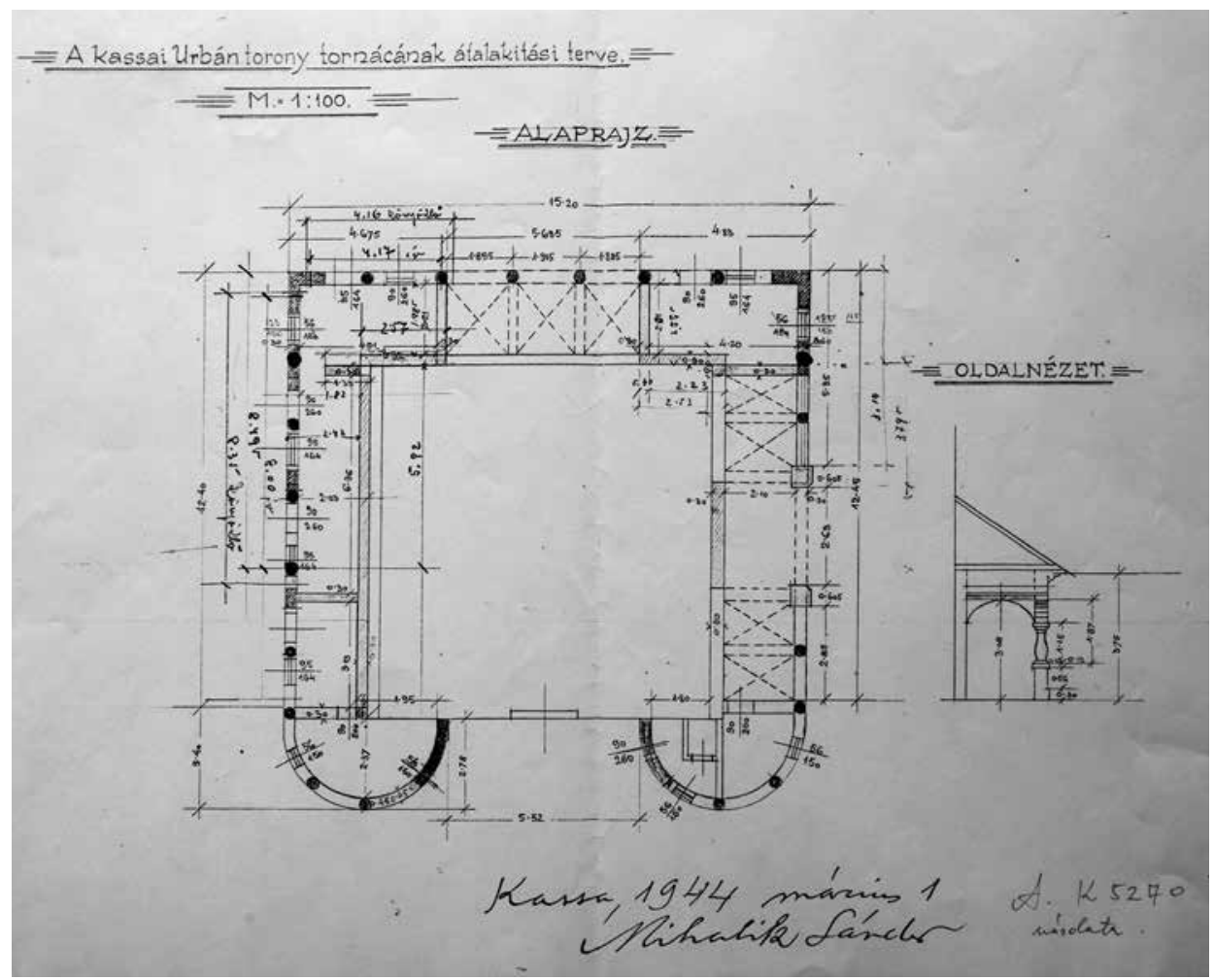

Obr. 8. Košice, Urbanova veža. Plán úpravy arkády Urbanovej veže (pravdepodobne Kladek Ferenc 1943), Forster Központ, Budapest - tervtár, K 5270.

Abb. 8. Košice, Urban-Turm. Plan für den Umbau der Arkade des Urban-Turms (wahrscheinlich Kladek Ferenc 1943), Forster Központ, Budapest - Tervtár, K 5270.

v kontakte s murivom veže a ak to okolnosti dovolia, odkryt' základové múry veže až po základovú špáru. Na povrchu sa vymedzil priestor $250 \times 180 \mathrm{~cm}$. Už v híbke niekol'kých desiatok centimetrov došlo k nálezom murovaných konštrukcií, ktoré ešte viac obmedzili možnosti híbenia. Išlo o vystupujúcu podmurovku arkádovej ochodze na severnej strane a dve línie kamenného múru (obr. 10) z južnej strany. Jedna z nich, južnejšia, patrila pozostatkom ohradového múru niekdajšieho cintorína. K murivu veže bol pristavaný, cezúra bola jasne viditel’ná. Severnejšia línia bola plytko založená a menej starostlivo murovaná. Mohla by byt' pozostatkom podmurovky niektorého z drobných obchodíkov, ktoré pri veži jestvovali v priebehu 19. storočia. V híbke $120 \mathrm{~cm}$ od súčasného terénu sa nachádzal základový odskok veže, odsadený od jej západnej steny o $40 \mathrm{~cm}$. Spomenutá podmurovka bola založená len po jeho úroveň. Pre zachovanie možnosti d’alšieho híbenia sondy bolo nutné podmurovku odstránit'. Následne sa odkryv v sonde postupne prehíbil až pod úroveň základovej špáry Urbanovej veže. Podarilo sa tak zdokumentovat' severný a západný profil a tiež celú híbku základového muriva veže (obr. 11, 12, 13). Južný profil výkopu dokumentovaný nebol. Pre zlepšenie už aj tak krajných bezpečnostných podmienok bol zošikmený na maximálnu mieru, aby sa predišlo závalu a slúžil i ako komunikačná a manipulačná strana sondy.

Základové murivo veže bolo murované z lomového kameňa spájaného maltou. Hmota základu bola vyrovnávacími špárami opticky rozčlenená na tri približne rovnaké časti s výškovým rozmedzím cca $85-90 \mathrm{~cm}$. V spodnej tretine základového muriva boli kamene na povrchu akoby 


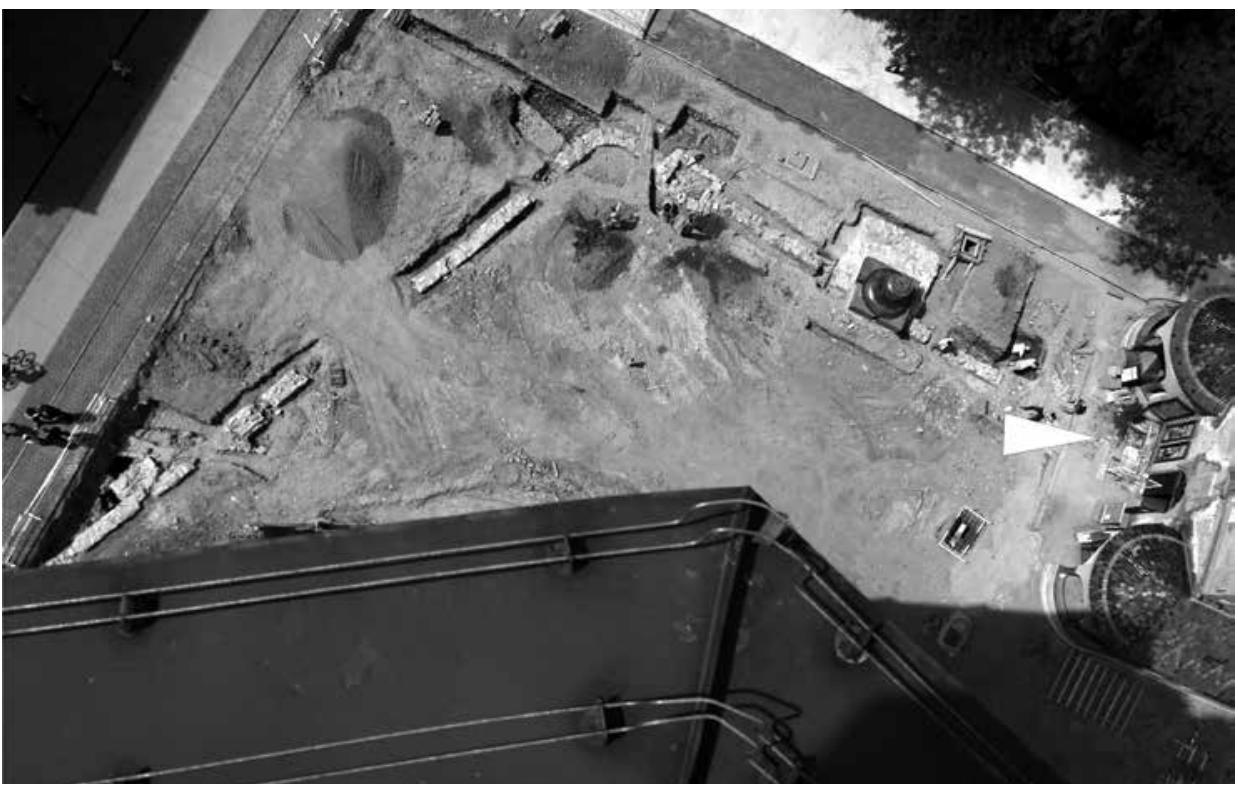

Obr. 9. Košice, Urbanova veža. Celkový pohl’ad na západnú čast' skúmanej plochy z veže dómu. Sonda 10/06 v styku s Urbanovou vežou je označená bielou šípkou.

Abb. 9. Košice, Urban-Turm. Gesamtansicht auf den Westteil der untersuchten Fläche vom Turm des Doms aus gesehen. Sondierschnitt 10/06, welcher direkten Kontakt mit dem Urban-Turm hat, wurde mit einem weißen Pfeil gekennzeichnet.

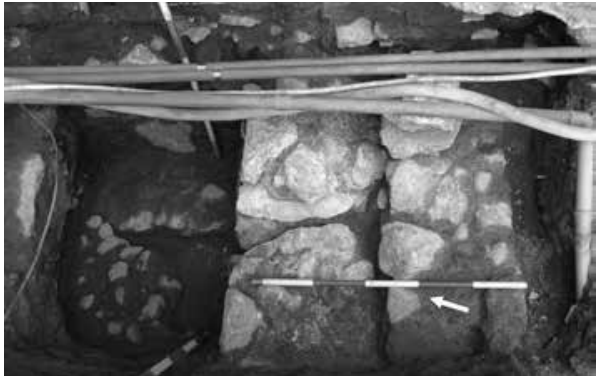

Obr. 10. Košice, Urbanova veža. Sonda $10 / 06$ na začiatku odkrývania. Od juhu múr cintorína a mladšia podmurovka, severne dlažba $z$ okruhliakov (vrstva 16), mierne prekrývajúca základový odskok veže.

Abb. 10. Košice, Urban-Turm. Sondierschnitt 10/06 zu Beginn der Freilegung. Von Süden Friedhofsmauer und jüngere Untermauerung, nördliche, einen Fundamentabsatz des Turms leicht überdeckende Pflasterung aus Knäpper-Steinen (Schicht 16). nia veže od úrovne súčasného terénu bola $385 \mathrm{~cm}$.

Sled vrstiev a ich kontakt s murivom veže sa dal dobre sledovat' na severnom profile sondy 10/06 (obr. 12,14). Tri najhlbšie položené vrstvy (1-3) v úrovni základovej špáry veže boli intaktné. Išlo o štrkové podložie, žltohnedú štrkovo-ílovú vrstvu a svetlohnedú pieskovo-ílovú vrstvu. Zaujímavé bolo súvrstvie označené číslami 4 a 5 , aj ked' išlo skôr o tri vrstvy. Vrstva 5, hrubá 15-23 cm, tvorená sivohnedým mazlavým ílom, bola z oboch strán ohraničená tenkými čiernymi vrstvami, zachovanými niekde lepšie, niekde iba nepatrne.Nepochybne išlo o drevo, 


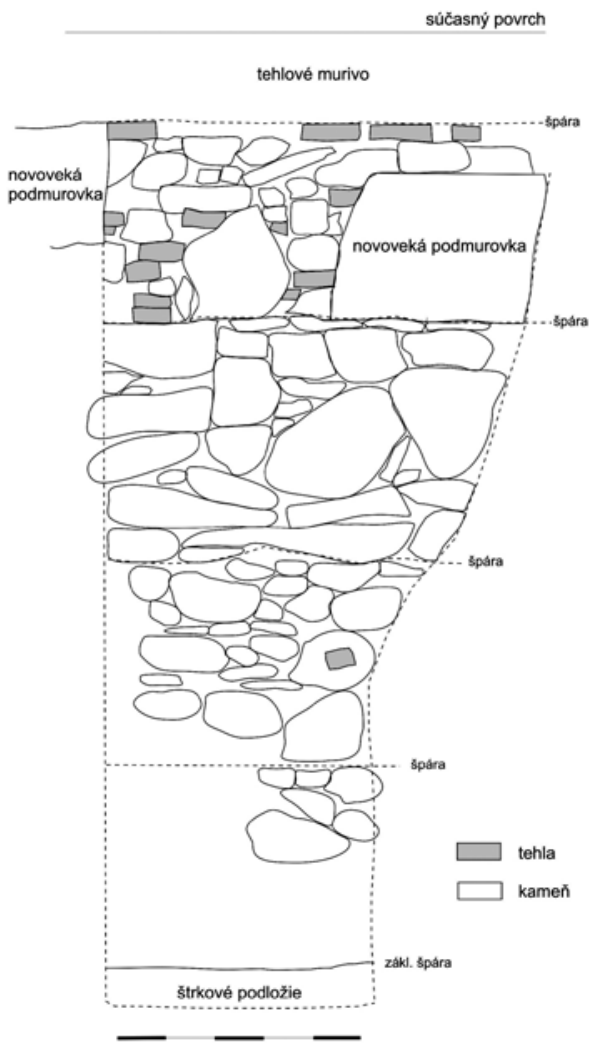

Obr. 11. Košice, Urbanova veža. Sonda 10/06, východný profil-základové murivo Urbanovej veže. Kresba L. Luštíková Abb. 11. Košice, Urban-Turm. Sondierschnitt 10/06, östliches Profil - Fundamentmauerwerk des Urban-Turms. Zeichnung L. Luštíková.

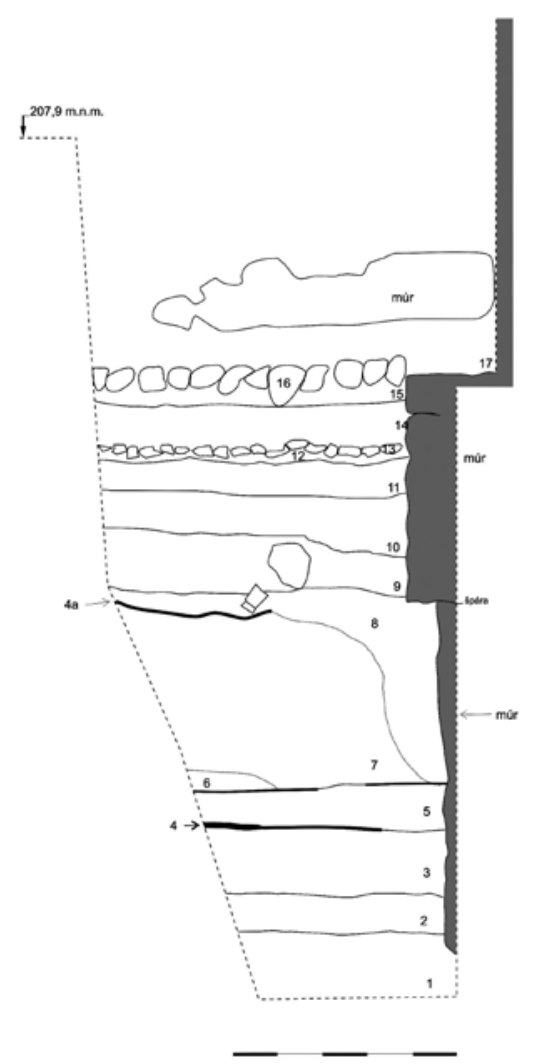

Obr. 12. Košice, Urbanova veža. Sonda 10/06, severný profil - sled vrstiev v styku so základovým murivom Urbanovej veže. Kresba L. Luštíková.

Abb. 12. Košice, Urban-Turm. Sondierschnitt 10/06, nördliches Profil - Schichtenfolge, die direkten Kontakt mit dem Fundamentmauerwerk des Urban-Turms hat. Zeichnung L. Luštíková.

jeho stav však bránil možnosti ho vypreparovat'. Viac-menej rovnobežné línie organických zvyškov dreva evokovali prítomnost’ neznámej stavebnej konštrukcie tvorenej z dosák, stav zachovania však neumožňuje k tomu zaujat' jednoznačné stanovisko. Vylúčit' nemožno ani náhodný výskyt bez zásahu človeka. Vrstvy 4 a 5 museli vzniknút' už v čase stredovekého osídlenia mesta, z vrstvy 5 pochádza niekol'ko keramických črepov, ktoré znesú zaradenie k najstarším horizontom vrcholnostredovekej keramiky z Košíc (tab. I:1-3). S rovnakým rámcovým datovaním, teda $v$ rozmedzí druhej polovice 13. až prvej tretiny 14. storočia, možno pracovat' i v prípade nálezov keramických črepov z vrstiev 7-9 (tab. I:4-18), ktoré spolutvorili $115 \mathrm{~cm}$ hrubé súvrstvie, pričom len vrstvy 7 a 8 mali hrúbku približne $90 \mathrm{~cm}$. V súvislosti s objektom Urbanovej veže zaujímavo vyznieva najmä vrstva 8 . Nemala totiž horizontálny charakter a opticky pôsobila ako zásah do vrstvy 7, a to práve v mieste kontaktu s murivom veže. Obe vrstvy mali ílovitý charakter, no líšili sa sfarbením. Vrstva 7 bola tmavá až čierna ílovitá naplavenina s drobnými fragmentmi organických zvyškov, ale i menších lomových kameňov, vrstva 8 bola svetlohnedá, bez viditel'ných prímesí. Vrstva 8 mala na l'avej, západnej strane profilu ešte horizontálny charakter a od vrstvy 7 ju oddel'ovala vrstvička dreva, možno dosky (obr. 12, označená ako 4a), smerom $\mathrm{k}$ murivu veže sa však výrazne zvažovala nadol a oddel'ovala tak od jej základového muriva celú vrstvu 7. V týchto miestach bola hranica oboch vrstiev rozpitá, nie úplne konkrétna. Otvorená 


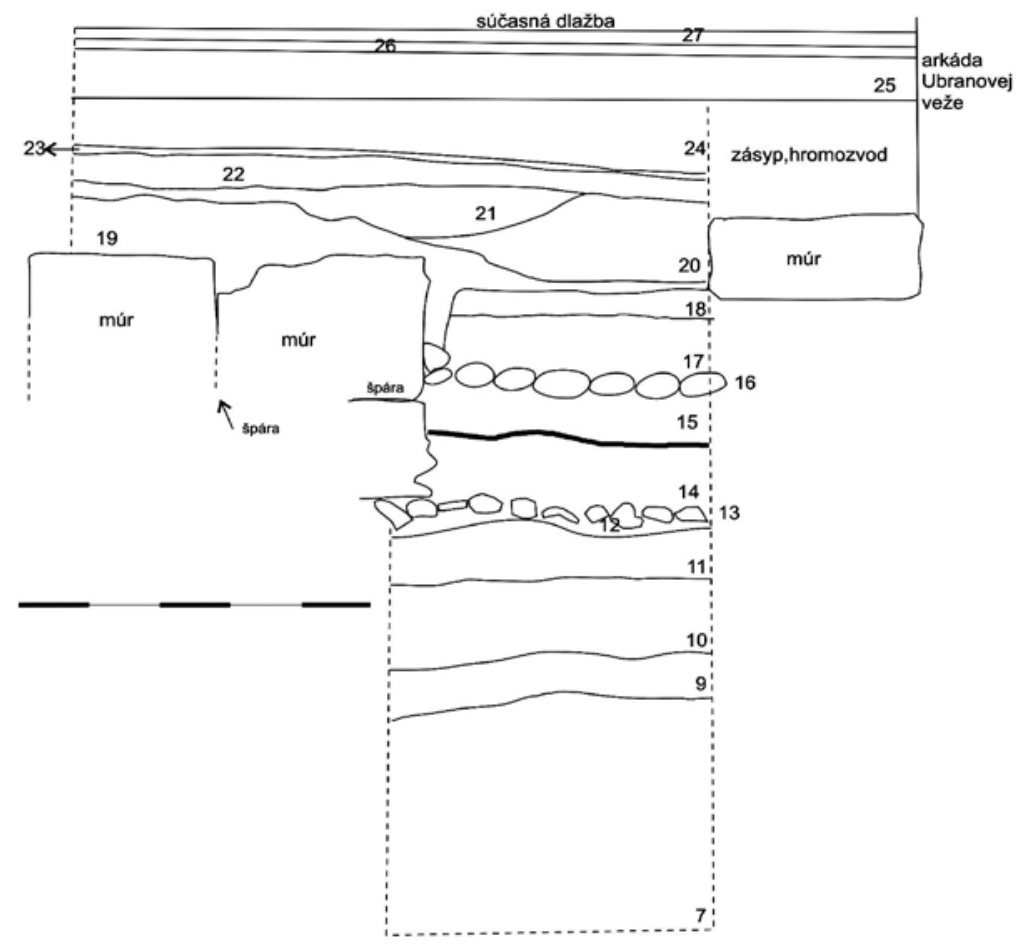

Obr. 13. Košice, Urbanova veža. Sonda 10/06, západný profil. Kresba L. Luštíková. Abb. 13. Košice, Urban-Turm. Sondierschnitt 10/06, westliches Profil. Zeichnung L. Luštíková.

je možnost', že išlo o pozostatok stavebného výkopu pre vežu. Za pozornost' snád' stojí i to, že rozhranie vrstvy 8 a vrstiev nad ňou sa zhodovalo s úrovňou vyrovnávacej špáry na murive veže, a to v mieste zvýrazneného odskoku základu.

Pri úvahách o datovaní výstavby Urbanovej veže stoja za pozornost' i vrstvy 10, 13 a 16. Červenkastá, prepálená vrstva 10 bola $20-30 \mathrm{~cm}$ hrubá a bola tvorená najmä stavebnou sutou $\mathrm{s}$ väčším počtom fragmentov škridlicovej strešnej krytiny (tab. II). Vrstva 13 bola s vel'kou pravdepodobnost'ou pozostatkom úrovne spevneného povrchu, teda dobovej exteriérovej pochôdznej nivelety. Tvorilo ju väčšie množstvo drobných úlomkov lomového kameňa, ubitých do ílovito-hlinitého podkladu. Črepový materiál z vrstiev 9-13 mal stále vrcholnostredoveký charakter (tab. I:19-22). Vrstva 16 patrila kvalitnej exteriérovej dlažbe z okruhliakových kameňov, uložených v pieskovom lôžku (vrstva 15). Pozoruhodným momentom je, že dlažba dosadala priamo na vrchnú úroveň základového odskoku veže a s najväčšou pravdepodobnostou vedome rešpektovala toto rozhranie (obr. 10). Našu pozornost' si tak zasluhuje vrstva 14, ktorá vypíňala priestor medzi dvoma spomenutými dobovými úrovňami spevnených povrchov námestia. Bola to $20-35 \mathrm{~cm}$ hrubá, tmavá, ílovito-hlinitá vrstva. Keramické črepy z nádob, pochádzajúce $\mathrm{z}$ vrstvy sú až na dve výnimky s istotou stredoveké (tab. III). Ide o premiešaný materiál $\mathrm{s}$ vrcholnostredovekou i neskorostredovekou zložkou. Z dvoch črepov tvoriacich výnimku je jeden zeleno glazovaný okraj pokrievky (tab. III:10), ktorého neskorostredoveké datovanie nemožno vylúčit'. Druhý črep z tela nádoby s čiastočným zeleným glazovaním, kde je stredoveké datovanie už menej pravdepodobné, má skôr novoveký charakter (tab. III:9). Výraznou nálezovou zložkou z vrstvy 14 je i viacero fragmentov glazovanej strešnej krytiny s rôznou farebnou škálou zelených, hnedastých či žltkavých odtieňov (tab. IV). Ide o škridle „bobrovky“ so 

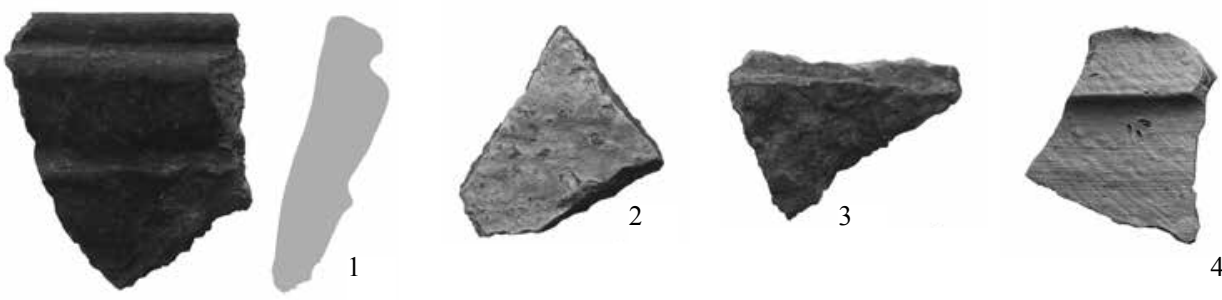

4
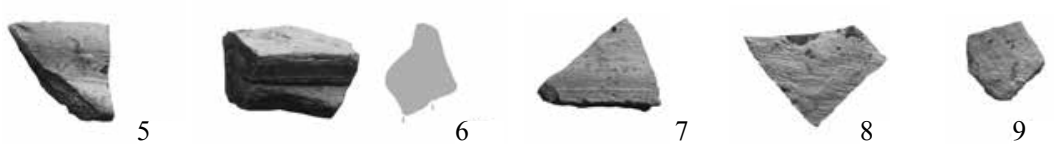

9
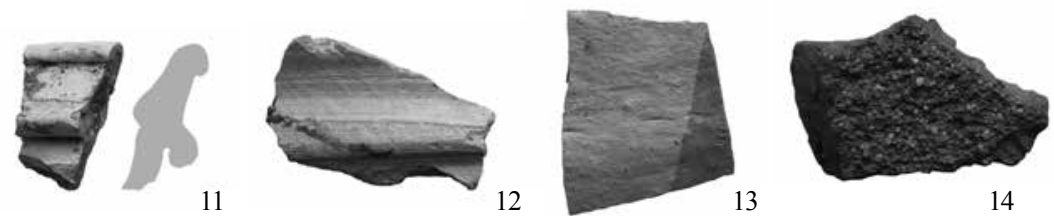

13

14
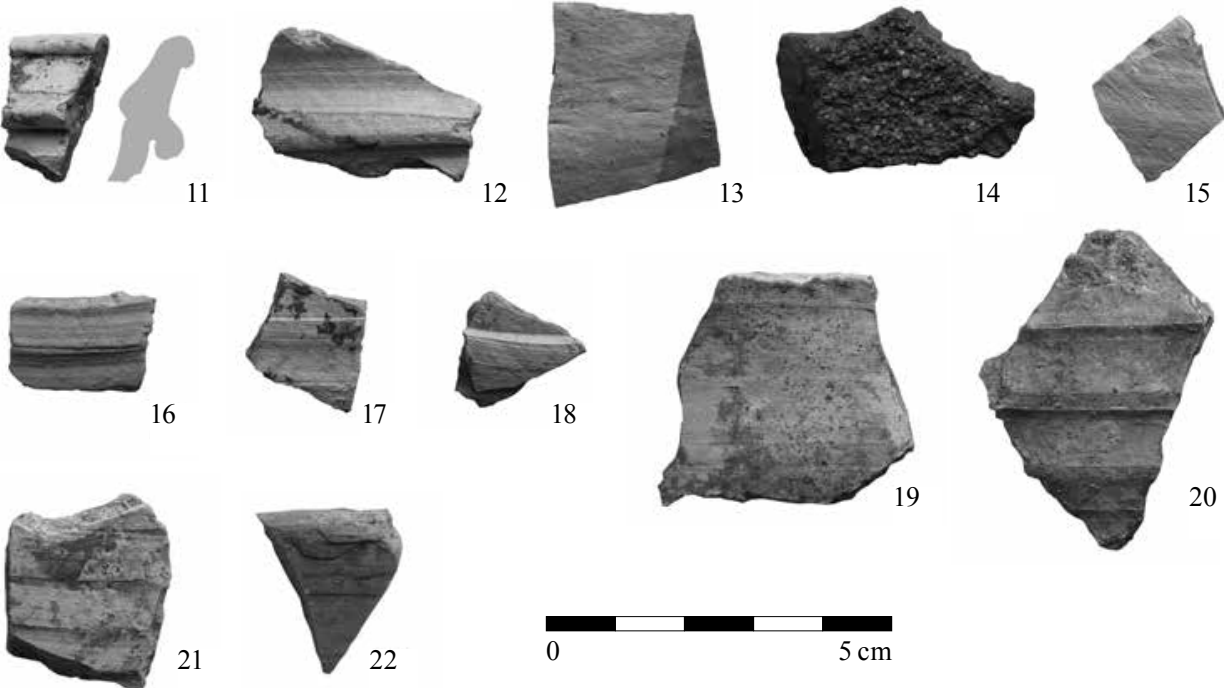

20

Tab. I. Košice, Urbanova veža. Sonda 10/06, 1-3 - črepy z vrstvy 5; 4-18 - črepy z vrstvy 8; 19-22 - črepy z vrstvy 12.

Tab. I. Košice, Urban-Turm. Sondierschnitt 10/06, 1-3 - Scherben aus Schicht 5; 4-18 - Scherben aus Schicht 8; 19-22 Scherben aus Schicht 12.

skosenou hranou oblúka, forma úchytu sa medzi nimi nezachytila. Napriek nevel'kému počtu fragmentov možno konštatovat', že tieto nálezy vykazujú vel'kú podobnost's už dlhšie známymi glazovanými škridlami z areálu dominikánskeho kláštora (Čurný 2010; v tlači; Rusnák v tlači), ktoré sú datované do obdobia najneskôr prvej polovice 16. storočia. Z vrstiev nad dlažbou z okruhliakov (vrstva 16) už pochádzal materiál, v ktorom prevládala novoveká zložka, aj ked' pre vel'kú fragmentárnost' črepov a absenciu chronologicky citlivejších nálezov je obtiažne bližšie než rámcové datovanie.

Pri pokuse o datovanie výstavby Urbanovej veže iba na základe výsledkov archeologického výskumu, teda realizácie sondy 10/06, je potrebné sústredit' sa na niekol'ko vyššie popísaných vrstiev severného profilu, a to predovšetkým vrstvy $8,10,13$ a 16 . Sivá ílovitá vrstva 8 , ktorá môže, no nemusí byt' pozostatkom stavebného výkopu pre základy veže, obsahovala výlučne vrcholnostredovekú keramiku s možnost'ou datovat' ju do obdobia pred polovicou 14. storočia. Rovnako však mohlo íst' o pozostatok inej dobovej terénnej depresie, vyplnenej svetlohnedým ílom, ktorú stavba veže neskôr narušila. Proti hypotéze stavebného výkopu hovorí i fakt, že 

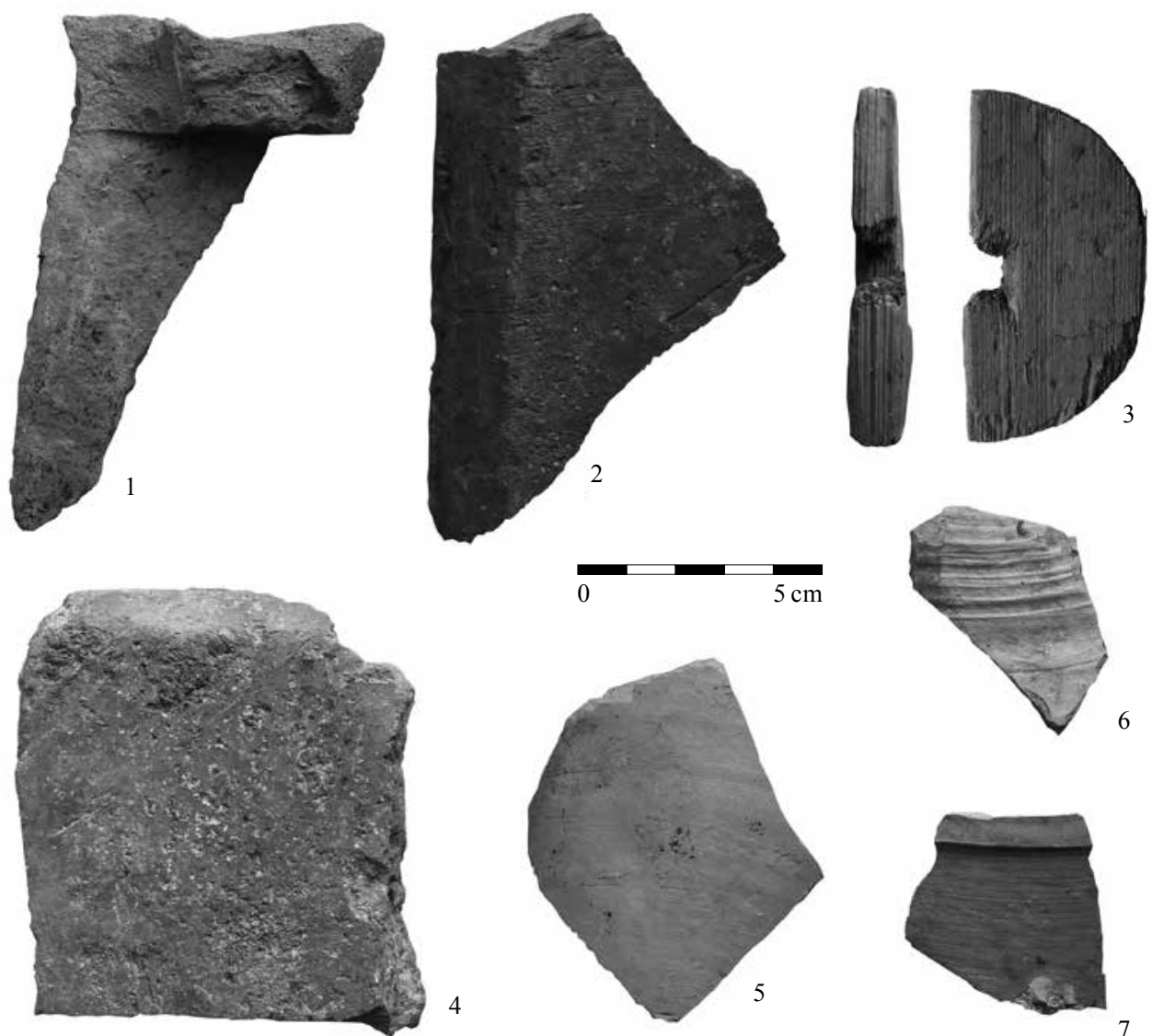

Tab. II. Košice, Urbanova veža. Sonda 10/06, vrstva 10. 1, 2, 4 - fragmenty škridlíc; 3 - drevený fragment, pravdepodobne súčast' maslenice; 5-7 - črepy.

Tab. II. Košice, Urban-Turm. Sondierschnitt 10/06, Schicht 10. 1, 2, 4 - Ziegelfragmente; 3 - Holzfragment, wahrscheinlich Bestandteil eines Butterfasses; 5-7 - Scherben.

vrstva zahŕňa iba približne tretinu hĺbky základu, na zvyšných úsekoch neboli zachytené stopy výkopu, a tiež prítomnost' mladších vrstiev 10 a 13 nad ňou, ktoré s vel'kou pravdepodobnostou vznikli ešte pred výstavbou veže. Možnost', že v prípade vrstvy 8 ide o pozostatok stavebného výkopu veže, sa tak dá vyhodnotit' ako málo pravdepodobná. Červená, prepálená vrstva 10 (ktorá má svoj ekvivalent i vo vrstve $4 \mathrm{z}$ východného profilu sondy 5/06) svojím datovaním do mladšieho horizontu vrcholnostredovekej keramiky a tiež početnými fragmentmi strešnej krytiny láka stotožnit' ju s vel'kým požiarom Kostola sv. Alžbety, ku ktorému došlo niekedy okolo roku 1380. Aj ked' nemožno vylúčit', že bola pozostatkom zánikového horizontu iného objektu, dôležité je, že materiál z vrstvy dovol'uje datovat' jej vznik do poslednej tretiny 14. storočia, teda do obdobia, ktoré tesne predchádzalo výstavbe veže podl'a tradičného datovania jej vzniku. Vrstva 13, spevnená úroveň exteriéru približne z obdobia záveru 14. storočia, sa nachádzala približne $30 \mathrm{~cm}$ pod úrovňou vrchného základového odskoku veže, čo rovnako vedie k predpokladu, že vznikla ešte pred jej výstavbou. Naopak, vrstva 16, kamenná exteriérová dlažba, je v stratigrafii severného profilu sondy 10/06 prvou vrstvou, ktorá s istotou vznikla až po výstavbe veže. Dosadala presne na rozhranie základu a nadzákladu, na jednom mieste základový odskok i mierne prekrývala (obr. 10). Ked’že vrstva 15 predstavovala iba čistý pieskový podklad dlažby, 

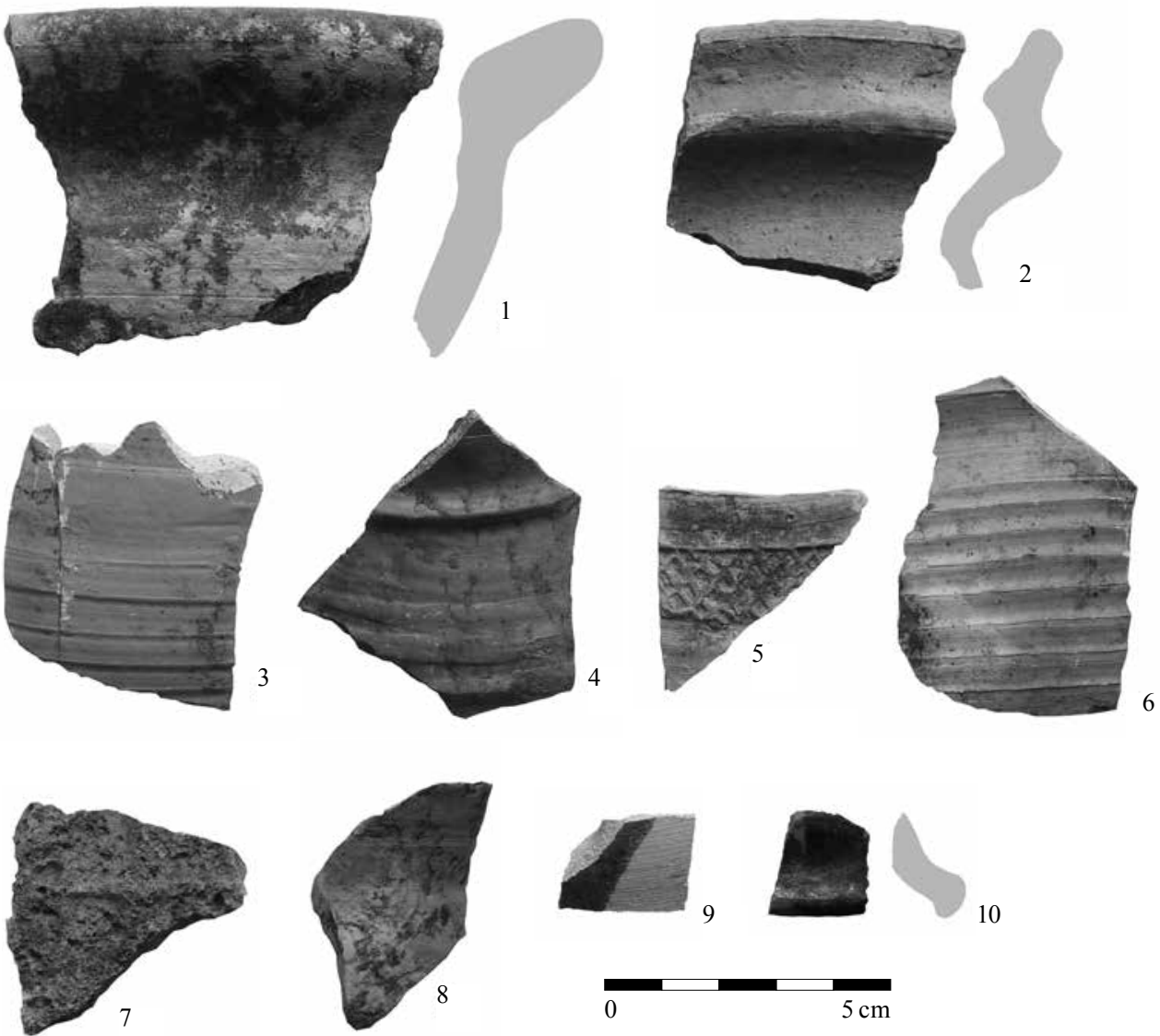

10

Tab. III. Košice, Urbanova veža. Sonda 10/06, črepy z vrstvy 14.

Tab. III. Košice, Urban-Turm. Sondierschnitt 10/06, Scherben aus Schicht 14.

klúčovou je pre nás vrstva 14. Jej materiálna náplň bola predstavená vyššie. Nemožno ju považovat' za chronologicky jednoliatu a napriek výrazne prevládajúcej stredovekej zložke je potrebné sústredit' sa na jej najmladšiu čast'. S výnimkou jediného črepu sa za takú dá považovat' kolekcia fragmentov glazovanej strešnej krytiny, pre ktorú sa ponúka rámcové datovanie do obdobia prvej polovice 16. storočia, zatial' najmä na základe relatívne blízkych, lepšie datovatel'ných analógií z areálu dominikánskeho kláštora. Ide o datovanie pred rok 1556, teda rok vel'kého požiaru mesta, kedy zhoreli i obe sakrálne dominanty, dóm i dominikánsky kostol. Požiar by mohol byt' považovaný za najpravdepodobnejší dôvod, prečo sa škridly, pôvodne asi zo strechy dómu, dostali do vrstvy 14. Črep, ktorý bol v súbore nálezov z vrstvy najmladší (tab. III:9), možno takmer s istotou označit' za novoveký, no pre jeho fragmentárnost' sa len t’ažko dá prekročit' hranica širokého rámca datovania. Zmiešaný charakter nálezov je dokladom, že vrstva 14 nereprezentuje krátkodobý horizont využívania plochy, ale vznikla skôr transferom chronologicky nejednotnej zložky, snád’ za účelom planírky terénu pred položením dlažby. Pre časové zaradenie jej vzniku nemožno pracovat's datovaním starším ako druhá polovica 16. storočia. Takéto datovanie i stratigrafická náväznost' exteriérovej dlažby už súvisiacej so vznikom veže viac-menej podporuje datovanie jej výstavby tak, ako ho prezentujú výsledky najnovšieho stavebno-historického výskumu (Krcho 2015). 

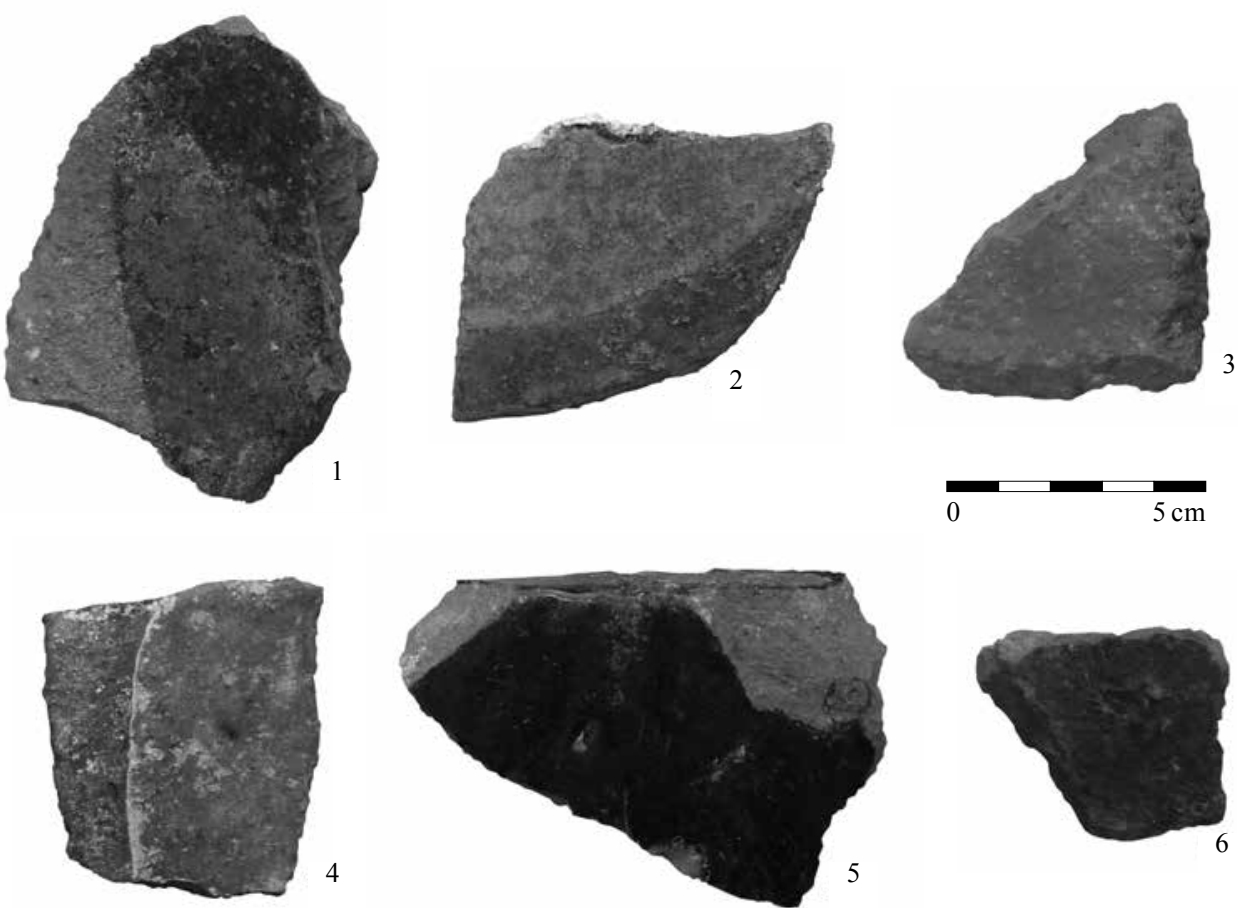

Tab. IV. Košice, Urbanova veža. Sonda 10/06, fragmenty glazovaných škridlíc z vrstvy 14.

Tab. IV. Košice, Urban-Turm. Sondierschnitt 10/06, Fragmente von glasierten Ziegeln aus Schicht 14.

Po stavebno-historickom výskume z roku 2015 sú zásadné interpretácie Evy Križanovej a Vojtecha Fifíka (spolu s Máriou Spoločníkovou), pokial' ide o datovanie najstaršej stavebnej fázy, spochybnitel'né: „Sondami v dlážke boli zistené tehlové opravy muriva v híbke cca 1,20m pod úrovňou dnešnej dlážky a nábeh krížovej klenby s odtlačkom podesty renesančného schodiska. Výskumy boli však len orientačné; híbkový archeologický výskum osvetlí aj domnienky o staršom vzniku zvonice, ktorá bola snád' súčast’ou ranostredovekého rádového kostola, pripadne špitála sv. Alžbety.“ (Križanová 1971, 206) Tieto zdanlivo kl'účové nálezové situácie v článku ani v správe nie sú nijako dokumentované. Dnes už disponujeme údajom o híbke založenia veže, cca $380 \mathrm{~cm}$ od súčasného terénu. Pri takomto založení by musel byt' suterén veže velmi nízky, so značne plytkou klenbou, čo je dost' nepravdepodobné, alebo musel byt' rozdelený na viac priestorov, čo je tak isto málo pravdepodobné. „Ostatné otvory zvonice“, okrem otvorov s gotickými rámami v hornej časti, ,(...) sa nám nezachovali. V nasledujúcom storočí boli rozšírené a vymenené za dnešné ranorenesančné. Analógiou s inými zvonicami s kostolnými vežami najmä na Spiši a v Šariši možno predpokladat', že boli osvetlované úzkymi štrbinovými oknami so širokými špaletami.“ (Križanová 1971, 206) Nálezové situácie v sonde 09 (obr. 15) a v nálezovej situácii 03 (obr. 16) dokladajú, že v neopracovanej časti sú kamenné rámy okien hlboko previazané $\mathrm{v}$ charakteristickom homogénnom murive, čo svedčí o tom, že boli osadené súčasne $\mathrm{s}$ výstavbou veže a v žiadnom prípade nie dodatočne. Po terajšom výskume je problematické aj vnímanie miery poškodenia veže požiarom v roku 1556, resp. pred rokom 1628. Eva Križanová uvádza: „Podl’a sondáži na omietkach sa zdá, že pôvodná gotická vrstva vápennej omietky s povrchom slonovej kosti bola vo vel'kej miere zničená a zachované fragmenty so špinavo šedým až čiernym povrchom sú zvyškami po ohni. Súčasne zhorel aj krov so strechou, nakolko v kapsách pôvodného uloženia trámov sme našli zuholnatelé drevené zvyšky. Oheñ zničil 


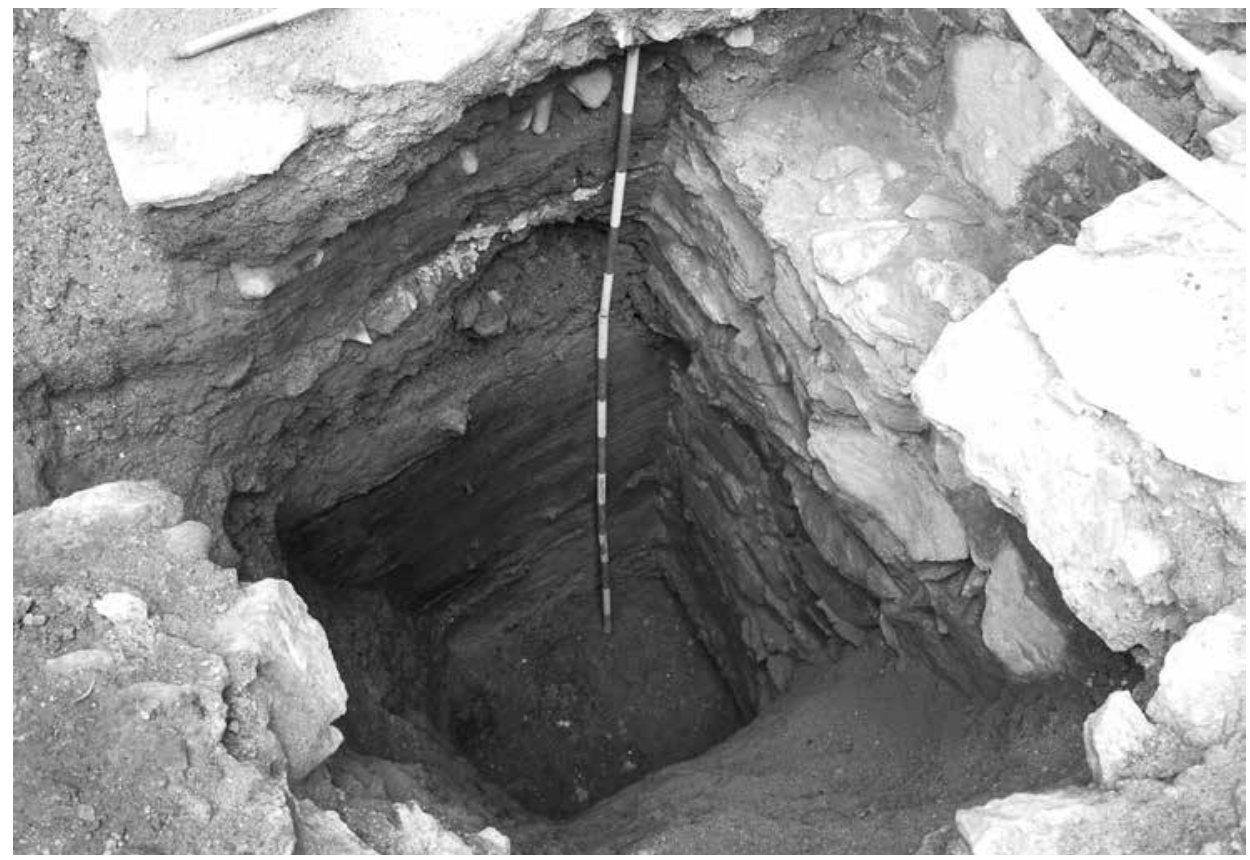

Obr. 14. Košice, Urbanova veža. Sonda 10/06, pohl'ad na severný a východný profil sondy po jej celkovom odkrytí.

Abb. 14. Košice, Urban-Turm. Sondierschnitt 10/06, Blick auf das nördliche und östliche Profil des Sondierschnitts nach seiner völligen Freilegung.

vnútornú dispozíciu a napadol zrejme aj pôvodné otvory v nižšich podlažiach. V rámci obnovovacích prác mesta sa pristúpilo aj $k$ oprave Urbanovej veže. Pri týchto prácach zrušili pôvodné úzke okná a nahradili ich dnešnými, polkruhovo uzavretými s esovitými rímsami v parapetoch $a v$ supraportách. Na južnej strane $v$ dnešnom prízemi použili tvar okna ukončeného v tvaroslovi týchto architektonických článkov napriek novému renesančnému cíteniu pretrvávajú gotizujúce znaky v detailoch." (Križanová 1971, 207, 208) Tomuto opät’ odporujú nálezové situácie v sonde 09 (obr. 15) a v nálezovej situácii 03 (obr. 16), kde vrstvy omietky prechádzajú plynule do ložnej malty aj okolo kamenných rámov okien. V sonde 13 (obr. 17) je dokonca zachovaný nepoškodený drevený armovací trám v ložnej malte pod parapetom okna s gotickou profiláciou. Nehovoriac o tom, že spomínané fragmenty omietky nie sú v inak precízne spracovanej podrobnej výskumnej správe nijako zdokumentované. Dôležité je pozorovanie o tom, že „napriek novému renesančnému cíteniu pretrvávajú gotizujúce znaky v detailoch“. Eva Križanová vníma „stredoveku' Urbanovu vežu aj v širšom kontexte, jednak v predpokladanej súvislosti s prestavbou farského kostola $(1971,205,206)$, ale aj v staršom stredovekom datovaní všetkých spišských zvoníc: „Na druhej strane umelecko-historický rozbor Urbanovej veže, ako aj orientačný výskum d'alšich spišských zvonic zrejme vyvráti doterajšiu mienku o kampanilách, ktoré vznikli ako typicky renesančné protestantské stavby pri staršich, pôvodne katolickych kostoloch a ukáže aj v tomto druhu pamiatok náväznost' na európsky vývoj umenia. Bude vecou d'alších tematických výskumov dokázat', že tieto zvonice sú stredovekého pôvodu nedelitel'nou súčastou stredovekých cirkevných stavieb.“ (1971, 203, 204) Mária Spoločníková okrem gotického profilu horných okien argumentuje podla nej charakteristickou štruktúrou gotickej omietky: „A napokon nasleduje pôvodná jasne rozpoznatel'ná gotická omietka na kamennom murive, u nás iba gotike vlastnej štruktúry s vel'kým množstvom kvalitného nažltlého vápna a praného piesku, kúskov slamy, drobných drevených štiepok a uhlikov, dávajúcich tvrdú a kompaktnú vrstvu." 


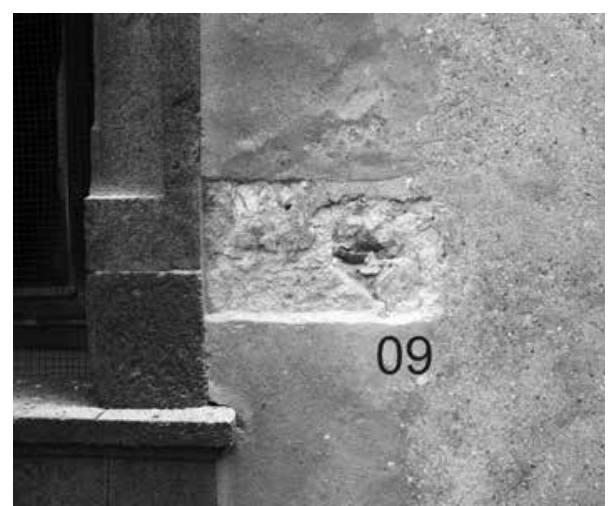

Obr. 15. Košice, Urbanova veža. Sonda $09(45 \times 26 \mathrm{~cm})$ v strednej časti vedl'a kamenného rámu okna druhého poschodia, na západnom priečelí, na pravej (južnej) strane. Abb. 15. Košice, Urban-Turm. Sondierschnitt $09(45 \times 26 \mathrm{~cm})$ im mittleren Teil neben dem Steinfensterrahmen im zweiten Stockwerk, Westfassade, rechte (südliche) Seite.

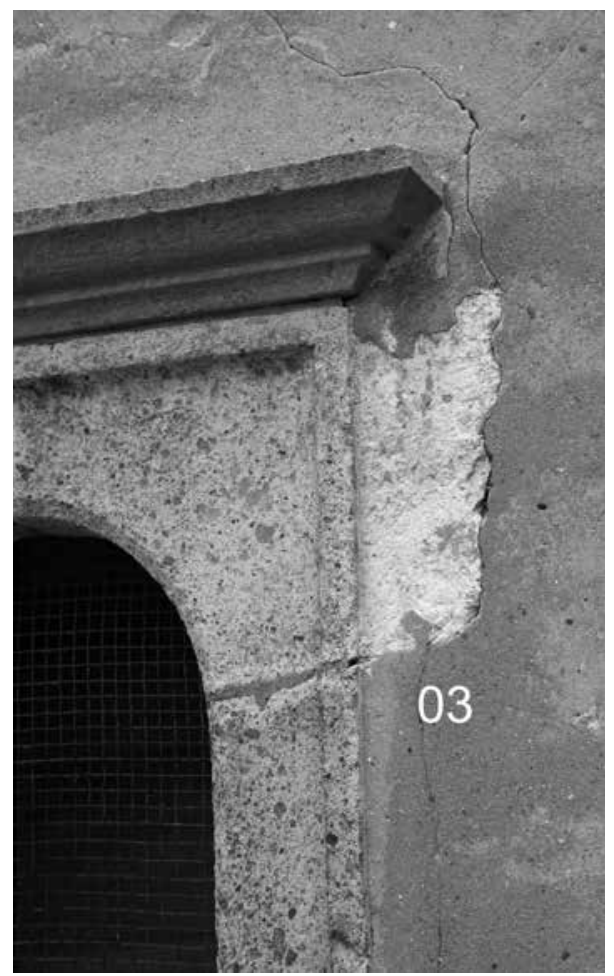

Obr. 16. Košice, Urbanova veža. Nálezová situácia 03 v hornej časti vedl'a kamenného rámu okna s archivoltou pod rímsou na pravej (južnej) strane na západnom priečelí. Abb. 16. Košice, Urban-Turm. Fundsituation 03 im oberen Teil neben dem Steinfensterrahmen mit Archivolte unter dem Sims auf der rechten (südlichen) Seite an der Westfassade.
$(1968,1,4)$ Uvedenú štruktúru spojiva sa nepodarilo identifikovat' $\mathrm{v}$ ani jednej odobranej vzorke. Naopak, pri porovnávaní ložných mált $\mathrm{v}$ prevládajúcom murive $\mathrm{z}$ lomového kameňa, miestami prekladaného tehlami, na viacerých úrovniach veže včítane časti s odstránenou fabiónovou rímsou a sgrafitami, ktorá je všetkými bez výhrad vnímaná ako renesančná, sme dospeli k záveru, že ide len o modifikácie toho istého spojiva (obr. 18; Krcho 2015, 9-12). Ak teda považujeme za renesančnú vrchnú čast' veže $\mathrm{s}$ fabiónovou rímsou a sgrafitami, tak musíme považovat' za renesančnú celú hmotu veže (obr. 19:1).

Z výskumnej správy Evy Križanovej a Vojtecha Fifíka (s čast’ou od Márie Spoločníkovej) je zrejmé, že hlavným motívom, ktorý ich viedol k stredovekému datovaniu, je forma kamenných rámov zvukových okien poschodia zvonovej stolice a čiastočne aj d'alšie detaily, napríklad profil kordónovej rímsy v tvare gotického odkvapového nosa medzi prvým a druhým poschodím, do určitej miery premodelovaný už v čase výstavby veže maltou totožnou s ložným spojivom. Tieto, ale aj d’alšie argumenty bádatel'ov, ako predpokladaný suterén, iná stredoveká úroveň vstupu, resp. predpokladaná sekundárna výmena štrbinových okien na okná s renesančnou profiláciou sú dnes už neudržatel'né. Napokon vznik veže v roku 1628 alebo po ňom potvrdzujú aj dve vzorky drevených prvkov, datované dendrochronologickou analýzou, ktorej autorom je Tomáš Kyncl. Boli odobraté práve z častí muriva bezprostredne vedl'a zvukových okien, teda presne $\mathrm{v}$ tých častiach, ktoré pre svoje gotické formy viedli bádatel'ov k stredovekému datovaniu. Čas výrubu dreveného dubového armovacieho trámu (sonda 13, obr. 17) sa podarilo rámcovo datovat' do obdobia po roku 1553. Tento trám bol zabudovaný tesne pod parapetom západného zvukového okna, ktoré má gotickú formu profilu rámu ukončeného lomeným oblúkom. V prípade jedlového trámu lešenia, na úrovni južného zvukového okna s rovnakou gotickou formou, sa dokonca podarilo datovat' rok výrubu na prelom rokov 1627/1628 (Kyncl 2016).

V druhej stavebnej fáze (obr. 19:2), niekedy v druhej polovici 17., resp. v prvej tretine 18. storočia (fázu je problematické zatial' presnejšie datovat'), vznikli nárožné bosáže 


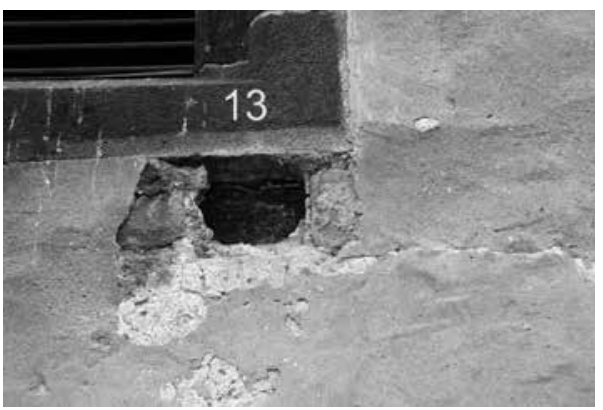

Obr. 17. Košice, Urbanova veža. Sonda $13(45 \times 26 \mathrm{~cm})$ pod kamenným rámom parapetu vel'kého zvukového okna s kamenným rámom ukončeným lomeným oblúkom, na tret’om poschodí veže na západnej strane.

Abb. 17. Košice, Urban-Turm. Sondierschnitt $13(45 \times 26 \mathrm{~cm})$ unter der steinernen Fensterbank des großen Schallfensters mit durch einen Spitzbogen abgeschlossenem Steinrahmen, drittes Stockwerk des Turms auf der Westseite. a kvádrovanie okolo všetkých okien, ktoré boli počas obnovy pred rokom 1969 odstránené takmer na celej veži, okrem úpravy okien nad prízemím.

V tretej stavebnej fáze (obr. 19:3) bol podl'a archívnych prameňov $\mathrm{v}$ roku 1754 prerobený krov veže a veža bola znova natretá načerveno. Tento krov so stupňovitým ukončením s arkádami je dobre viditel'ný na viacerých zobrazeniach z 18. storočia. Z tejto stavebnej fázy veže sa nezachovalo nič. Krov v roku 1775 vyhorel. Predpokladáme, že počas požiaru sa zrútila masívna fabiónova rímsa s lunetami nad sgrafitami, ktorú po roku 1775 v štvrtej stavebnej fáze (obr. 19:4) nahradili redukovanou nižšou a bez lunet. Tento stav krovu veže sa zachoval do požiaru v roku 1966.

V piatej stavebnej fáze (obr. 19:5) - nie-

kedy pred rokom 1839 - pravdepodobne postupne okolo veže postavili dost' nesúrodé prístavby krámikov, ktoré v roku 1880 úplne zbúrali. Z tejto stavebnej fázy sa zachovali iba zvyšky základov, ktoré boli archeologicky zachytené, resp. sú zdokumentované na dobových fotografiách. Rovnako je fotograficky zdokumentovaná veža aj po zbúraní krámikov.

V šiestej stavebnej fáze (obr. 19:6) bola podl’a plánu Otta Sztehla z roku 1909 (obr. 7) postavená arkáda, do ktorej umiestnili najprv 28 kamenných náhrobkov pochádzajúcich z obnovy dómu. Čiastočne boli obnovené krámiky na nárožiach prístavby. V spodnej časti bola veža obmurovaná $30 \mathrm{~cm}$ hrubým tehlovým múrom, „klenby“ tejto fázy boli už v tom čase zhotovené z tenkých betónových škrupín. Úpravy boli dokončené v roku 1912 (obr. 18).

V siedmej stavebnej fáze (obr. 19:7) boli urobené d’alšie úpravy ochodze, ktoré dokončili v roku 1947 podl'a plánu podpísaného Sándorom Mihalikom z roku 1944. Ten však vychádzal zo starších návrhov Ferenca Kladeka zo 14. apríla 1943 (obr. 8). Obidva plány Sándor Mihalik iba schval'oval v mene MOBu (Mủemlékek Országos Bizotsága - Krajinská komisia pamiatok). Mená architektov úpravy, K. a G. Lux, uvedené v Súpise pamiatok sú podla nášho názoru nesprávne (Güntherová-Mayerová 1968, 99). Plány na obnovu veže a umiestnenie lapidária v roku 1947 predložili po pričlenení Košíc k Československu na posúdenie aj Povereníctvu školstva a osvety v Bratislave (odbor ochrany pamiatok). Povereníctvo plány (v archíve sa nenachádzajú) dodatočne schválilo 22. novembra 1947 (Archív PÚ SR, šk. č. 47). Počas tejto obnovy boli poprekladané niektoré náhrobky a lapidárium bolo doplnené o d’alšie epitafy, uložené dovtedy vo Východoslovenskom múzeu. Po úprave ich bolo spolu 36 (jeden bol poskladaný z dvoch rôznych náhrobkov).

V ôsmej stavebnej fáze (obr. 19:8) - po požiari 3. decembra 1966 - bola veža reštaurovaná. Vstavali do nej ocelové schodisko a priestory pre expozíciu lejárstva v Košiciach. Strechu veže zakryli vysokým gotizujúcim kovovým krovom. Obnovu veže dokončili v roku 1969. V roku 1996 do nej vložili kópiu pôvodného zvonu Urban. Jeho pôvodné časti, poskladané z fragmentov, sú uložené na námestí pred vežou. Dnes je vo veži čiastočne expozícia Východoslovenského múzea, čiastočne panoptikum voskových figurín.

V novšej umeleckohistorickej literatúre, snád' počnúc štúdiou Erwina Panofského z roku 1930 (Panofsky 1930), je dobre dokladované prežívanie gotických foriem aj v 16. a 17. storočí (Panofsky 1981; 2013, 207-209). Týmto problémom sa zaoberal aj Rudolf Wittkover (1974, 191) a mnohí d'alší. V kontexte Uhorska uvádza príklady prežívania gotických foriem v 16. a 17. storočí Tibor Koppány (1990, 454), novšie i Gergely Domonkos Nagy (2013). Najbližšie ku Košiciam sú úpravy kostolov s použitím gotických foriem v Tarpe (1592), v Szerencsi (1595) 
a v Sárospataku (od 1540). Koppány upozorňuje aj na to, že podl'a pravidiel cechu murárov a kamenárov v Košiciach v roku 1573 bolo potrebné na prijatie do cechu zhotovit': „,krížovú klenbu, okno s delením v tvare križa, alebo oporný pilier s fialou“,3 pričom predpokladá, že pod zhotovením krížovej klenby mysleli jej rebrový svorník, lebo samotná klenba bola príliš jednoduchým produktom, hlavne pre kamenára $(1990,454)$. Prakticky tie isté pravidlá platili aj pre cech murárov a kamenárov v Kluži (Cluj-Napoca) - podl’a cechových pravidiel z roku 1589 (Koppány 1990, 454). Doloženým prežívaním starších foriem aj v Košiciach sa gotizujúce formy predovšetkým horných okien na úrovni zvonovej stolice dajú vysvetlit' ovel'a jednoduchšie ako uvedené protirečenia. Dôsledkom obluby gotických foriem sú pravdepodobne aj sekundárne použité kamenné fragmenty nad oknami prvého poschodia (v priebehu pripravovanej obnovy to bude potrebné po postavení lešenia overit'). Sgrafitové hlavy bojovníkov boli zhotovené na základe nejakých grafických predlôh, početné analógie takýchto sgrafít poznáme z Moravy (Weisser 2013, 46-48). Na moravský pôvod týchto foriem poukazuje aj rovnaký pôvod architekta Martina Lindnera. Na základe vedút zo začiatku 17. storočia (obr. 1, 2) predpokladáme, že helmica veže po výstavbe bola stupňovito členitá s nárožnými vežičkami. Aj pri datovaní celej veže do roku 1628-1629 nie je možné úplne vylúčit aj archívne doloženého a na Houfnagelovej rytine (obr. 3) zachyteného predchodcu veže ako nejaké relikty staršieho objektu, zabudované v skúmanej stavbe. O týchto častiach však nateraz nevieme povedat' nič určité.

Podla výsledkov stavebno-historického výskumu (Krcho 2015) podloženého aj dendrochronologickou analýzou (Kyncl 2016) sa javí byt' celá veža, včítane časti pôvodnej masívnej fabiónovej rímsy s lunetami a sgrafitami, postavená v jednej - prvej stavebnej fáze, v roku 1628, resp. 1629, architektom Martinom Lindnerom pre zvon Urban, ktorý dovtedy nemali kde umiestnit'. Takéto datovanie umožňujú aj písomné pramene a takto

3 Pôvodne publikoval Kemény 1904, 78: „(...) ein Kreutz gewölb oder ein Kreutzfenster zusetzen ohne Richtscheibl oder Schussblei oder aberspitzeker Pylaster:“

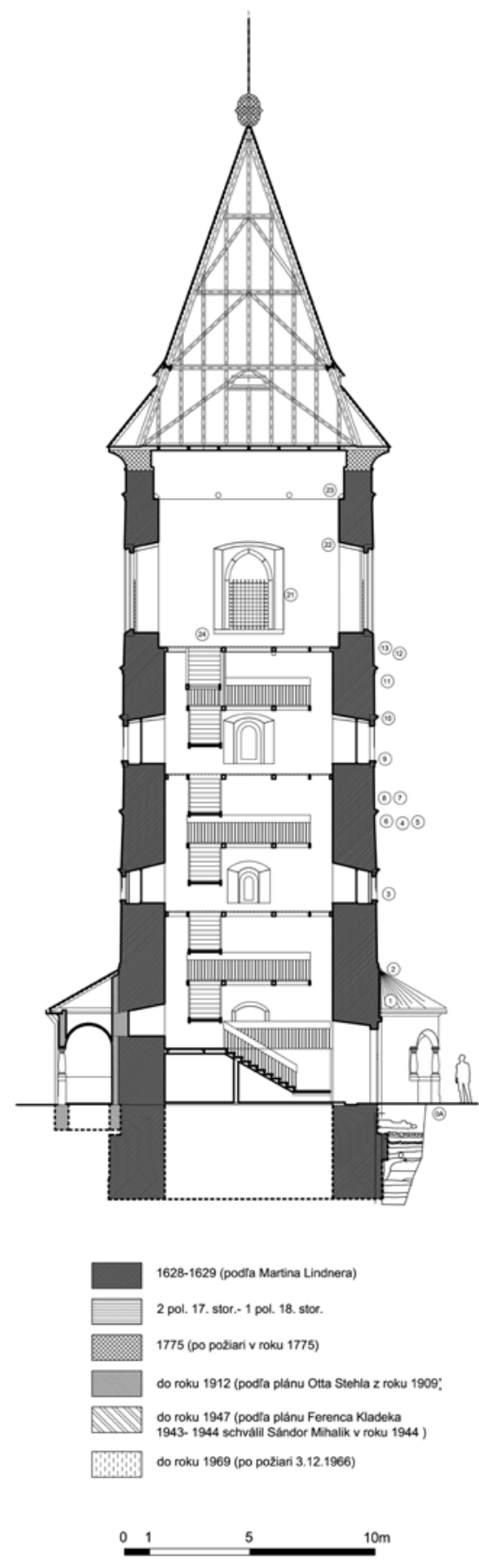

Obr. 18. Košice, Urbanova veža. Rez A-A, vo východo-západnom smere s pohl'adom na južnú čast' veže.

Abb. 18. Košice, Urban-Turm. Schnitt A-A, in Ost-West-Richtung mit Blick auf den Südteil des Turms. 

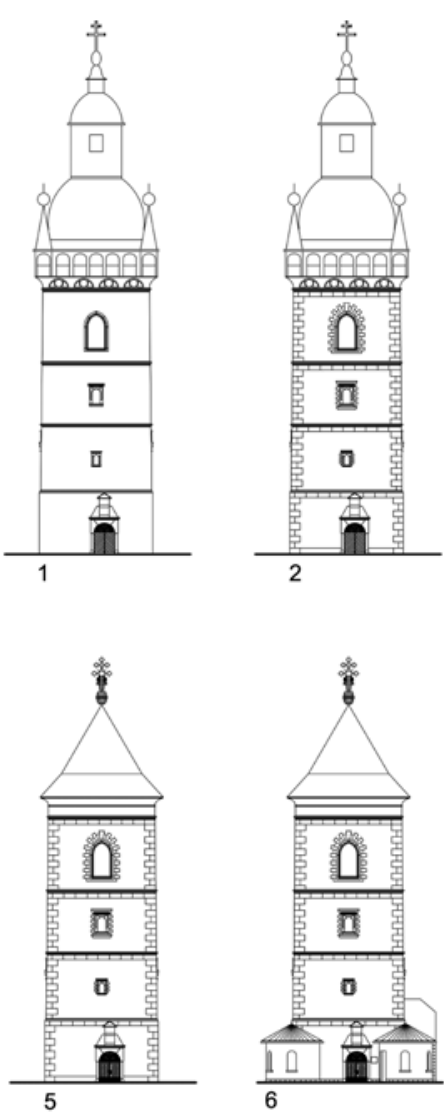
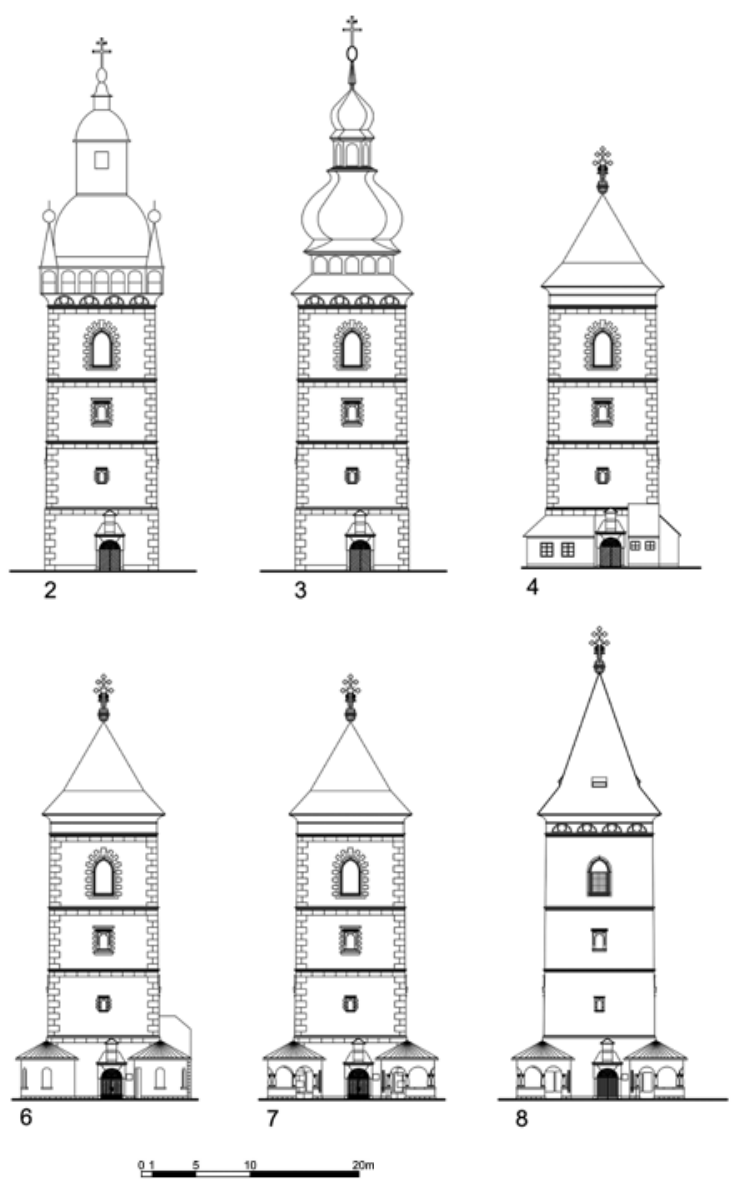

Obr. 19. Košice, Urbanova veža. Teoretická rekonštrukcia vývoja veže: 1 - po roku 1629; 2 - koniec 17. storočia; 3 - po roku $1754 ; 4$ - pred rokom $1839 ; 5$ - po roku $1880 ; 6$ - po roku $1912 ; 7$ - po roku $1947 ; 8$ - po roku 1969.

Abb. 19. Košice, Urban-Turm. Theoretische Rekonstruktion der Entwicklung des Turms: 1 - nach 1629; 2 - Ende 17. Jahrhundert; 3 - nach 1754; 4 - vor 1839; 5 - nach 1880; 6 - nach 1912; 7 - nach 1947; 8 - nach 1969.

bádatelia datujú vežu vo všetkých publikáciách pred druhou svetovou vojnou a mnohí aj po nej. Ani výsledky archeologického výskumu v bezprostrednom okolí veže takýmto záverom neodporujú. Všetko, čo je z veže viditel'né dnes, bolo postavené najskôr v roku 1628, resp. 1629.

Príspevok vznikol v rámci projektu 1/0727/17 vedeckej agentúry VEGA.

\section{Pramene a literatúra}

AMK, H: Archív mesta Košíc, Supplementum H, Missiles 1628, 6229/52.

AMK, Mag.: Archív mesta Košíc, Magistrátus1880, 1825 (szám).

AMK, Prot.: Archív mesta Košíc, Protocollum 1556-1608. 
Archív PÚ SR, šk. č. 47: Archív Pamiatkového úradu Slovenskej republiky, fond pamiatkové orgány na Slovensku (1919-1951), šk. č. 47, Košice - Dodatočné schválenie kolonády pod Urbanovou vežou, spis číslo 207637/1947-BIII./1.

Civitates Orbis Terrarum 1617, plate 31: Civitates Orbis Terrarum, vol. 6, Braun \& Hogenberg.

ČURNÝ, M., 2010: Nové nálezy stredovekej a včasnonovovekej stavebnej keramiky z Košíc - Neue Funde mittelalterlicher und frühneuzeitlicher Baukeramik aus Košice, AH 35, 253-270.

- v tlači: Tehla a stavebná keramika v architektúre stredovekých a včasno novovekých Košíc. In: Forum Urbes Medii Aevi IX/1-2. Cihla a stavební keramika v městské architektuře středověku a novověku ve střední Evropě. Brno.

DIVALD, K., 1899: A felső magyar országi renaissance-építészet II., Magyar mérnök és építész egylet közlönye XXXIII./VI., 219-224.

DOMONKOS NAGY, G., 2013: Gothicized buildings and the role of symbols in Baroque architecture, Periodica Polytechnica, 69-76.

Forster Központ, 5187: Forster Központ, Budapest - tervtár, 5187.

GAŠPAR, J., 2011: Košice. Pohl'ady do histórie mesta na starých pohladniciach. I. čast'. Poprad.

GROŠKO, I., 1980: Košice vo výtvarnom umení. Košice.

GÜNTHEROVÁ-MAYEROVÁ, A., red., 1968: Súpis pamiatok na Slovensku II. Bratislava.

HALAGA, O. R., 1992: Počiatky Košíc a zrod metropoly. Košice.

HENNING, J.-RUSNÁK, R., 2008: Nové dendrodáta z Košíc - The new dendro data from Košice. In: Ve službách archeologie, sv. 1 (Hašek, V.-Nekuda, R.-Ruttkay, M., edd.), 151-156. Nitra.

JUCKES, T., 2011: The Parish and Pilgrimate Church of St Elizabeth in Košice. Turnhout.

KEMÉNY, L., 1901/1905: Az Orbántorony. Kassavidéke.

- 1904: Kassai építőmesterek in Magyarmérnök és építészegylet Közlönye.

- 1916: Mü- és müvelödéstörténeti adatok Kassa város életéből a rokokó korában, Archeológiai értesítő.

KEREKES, Gy., 1902: Nemes Almássy István kassai kereskedő és bíróüzleti-, köz- és családi élete 15731635. Budapest.

- 1943: Bethlen Gábor fejedelem Kassán 1619-1629. Budapest.

KISARI BALLA, Gy., 1996: Törökkori várrajzok Stockholmban. Budapest.

KOPPÁNY, T., 1990: Gotizáló tendenciák a Magyarországi későreneszánsz építészetben. In: Collectanea Tiburtiana, Tanulmányok Klaniczay Tibor tiszteletére (Galavics, G.-Herner, J.-Keserü, B., edd.), 451461. Szeged.

KORPONAY, J., 1866-1870: Abauj vármegye monográphiája I. Kassa.

KRCHO, J., 1992: „Standing Watch in Kassa“. City walls and watchtowers and their phases of constructions, Periodica Polytechnica, Architecture, 36, č. 1-4.

- 2015: Urbanova veža - Košice. Pamiatkový výskum. Nepublikovaný rukopis.

Krigsarchivet, handritade Kartverk Nr. 23/37: Kungliga Krigsarchiv et Stockholm, handritade Kartverk Nr. 23/37.

KRIŽANOVÁ, E., 1971: Urbanova veža v Košiciach, Monumentorum Tutela - Ochrana pamiatok 7 , 203-236.

KRIŽANOVÁ, E.-FIFÍK, V., 1968: Urbanova veža v Košiciach, I. etapa podrobného výskumu, Slovenský ústav pamiatkovej starostlivosti a ochrany prírody Bratislava. Nepublikovaný rukopis. Súčastou tohto dokumentu je text M. Spoločníkovej, Zpráva o prevedení prieskumu na objekte „Urbanova veža“v Košiciach, 53-58.

KUHN, I., 1982: Renesančná architektúra na Slovensku, ARS 16, č. 2, 16-72.

KYNCL, T., 2016: Výskumná správa č. 086-16, Dendrochronologické datování dřevěných konstrukčních prvků z Urbanovy věže v Košicích. Nepublikovaný rukopis.

Landesarchiv Karlsruhe HfK VI, fol. 39: Landesarchiv Baden-Württenberg, Generallandesarchiv Karlsruhe HfK VI, fol. 39.

Landesarchiv Karlsruhe HfK XIII, fol. 50-52: Landesarchiv Baden-Württenberg, Generallandesarchiv Karlsruhe HfK XIII, fol. 50-52.

Landesarchiv Karlsruhe HfK XV, fol. 47: Landesarchiv Baden-Württenberg, Generallandesarchiv Karlsruhe HfK XV, fol. 47.

Landesarchiv Karlsruhe HfK XVII, fol. 16: Landesarchiv Baden-Württenberg, Generallandesarchiv Karlsruhe HfK XVII, fol. 16.

MIHALIK, J., 1897: Kassa és környéke, tájékoztató kalauz. Kassa.

MIHALIK, S., 1943: Öt év műemlékvédelme és múzeumi munkája - Pät rokov ochrany umeleckých pamiatok a muzeálnej práce 1938-1943. Kassa. 
MOL, Térképtár: S 11 No 0490:1, plán je prístupný aj na webe: http://mol.arcanum.hu/terkep/ opt/a121112htm? $\mathrm{v}=$ pdf \&q=CIM\%3D\%28Delineatio\%29\%20and\%20TRGY\%3D\%28kassa\%29\&a=list, cit. 14. 12. 2014.

ÖNB, cod. 8609: Vienna, Österreichische Nationalbibliothek, cod. 8609, fol. 56.

ÖNB, cod. 8623: Vienna, Österreichische Nationalbibliothek, cod. 8623, fol. 23 a 24.

PANOFSKY, E., 1930: Das erste Blatt aus dem Libro Giorgio Vasari, Städel-Jahrbuch VI, $25-72$.

- 1981; 2013: Význam ve výtvarném umění. Praha.

Relatio 1603, No. 69: Relation. MOL (Magyar Országos Levéltár), E 158, Mikrofilm: MOL, Filmtár 1862. Prameň bol nedávno publikovaný v pôvodnom znení i so slovenským prekladom a opatrený komentárom: Duchoň, J., Relation, analýza prameňa, Východoslovenský pravek X, 2013, 291-332.

RUSNÁK, R., 2013: Desat' rokov archeologického výskumu v jadre mesta, Historická revue, špeciál, 11-14.

- v tlači: Vrcholno stredoveká keramika z výskumu v Košiciach, pri Dóme sv. Alžbety. Zborník z konferencie Hlinené nádoby 1000-1700, Trebišov, 2006.

- v tlači a: Nálezy stavebnej keramiky z výskumu gotickej fázy dominikánskeho kláštora v Košiciach. In: Forum Urbes Medii Aevi IX/1-2. Cihla a stavební keramika v městské architektuře středověku a novověku ve střední Evropě. Brno.

SPOLOČNÍKOVÁ, M., 1968: Urbanova zvonica je gotická, Východoslovenské noviny, 26. januára 1968, 1 a 4.

SPS 1968: Günterová, A., red., Súpis pamiatok na Slovensku. Zväzok druhý. K-P. Bratislava.

SZIKLAY, J.-BOROVSZKY, S., 1896: Magyarország vármegyéi és városai I I., Abaújvármegye és Kassa. Budapest.

ŠOBA Prešov, inv. č. 275: Magistrát mesta Prešov, inv. číslo 275, signatúra 2118, Matrika prijatých do zväzku mesta 1538-1676 (folia 64r).

TUTKÓ, J., 1861: Szabadkirályi Kassavárosának történeti évkönyve. Kassán.

UHORSKÝ SIMPLICISSIMUS, 1975: Uhorský Simplicissimus. Bratislava. Preklad a epilóg: Jozef Vlachovič.

URBANOVÁ, N., 2003: Základy stredovekých miest - urbanistická štruktúra. In: Buran, D. a kolektív, Dejiny slovenského výtvarného umenia. Gotika, 71-86, obr. 40. Bratislava.

- 2003a: Architektúra profánneho a sakrálneho priestoru. In: Buran, D. a kolektív, Dejiny slovenského výtvarného umenia. Gotika, 277-284, obr. 235. Bratislava.

- 2009: Urbanizmus a architektúra miest v období renesancie. In: Rusina, I. a kolektív, Dejiny slovenského výtvarného umenia. Renesancia, 247-261, 704. Bratislava.

WEISSER, P., edit., 2013: Sgrafita zámku v Litomyšli. Pardubice.

WICK, B., 1928: A háromszáz éves kassai szent Orbán-torony, 1628-1928. Košice.

- 1928a: Kassarégitemetői templomi kriptái és síremlékei. Košice.

- 1933: Kassarégisíremlékei, XIV-XVII sázad. Košice.

- 1941: Kassa története és müemlékei. Kassa.

WITTKOWER, R., 1974: Gothic versus Classic. Architectural Projects in Seventeenth-Century Italy. New York.

\section{Zusammenfassung}

\section{Zur Datierungsproblematik der Entwicklungsphasen des Urban-Turms in Košice}

Der Urban-Turm ist ein massiver, viergeschossiger Bau im Zentrum des historischen Stadtkerns von Košice, der als Glockenturm des St. Elisabeth-Doms, der Hauptpfarrkirche von Košice, errichtet wurde. In der bisherigen Fachliteratur herrschen zwei Meinungen über die Datierung seiner Errichtung vor. Von den älteren Historikern wird der Bau des ganzen Urban-Turms in das Jahr 1628 oder 1629 datiert, neuere Quellen ziehen einen mittelalterlichen, im Jahr 1628 lediglich umgebauten Grundbau in Betracht. Es ist offensichtlich, dass das Hauptmotiv, das sie zu einer mittelalterlichen Datierung brachte, auf der gotischen Form des Steinrahmens der Schallfenster in der Etage basiert, in der sich der Glockenstuhl befindet (Križanová 1971; Križanová-Fifík 1968).

In den Jahren 2014-2015 wurde im Rahmen der geplanten Renovierung des Bauwerks eine bauhistorische Untersuchung des Turms durchgeführt (Krcho 2015). Die Untersuchung erfolgte hauptsächlich anhand von zerstörungsfreien Methoden, aber auch durch Sondierschnitte. Insgesamt wurden 34 Sondierschnitte gelegt. Die in zwei der Sondierschnitten gemachten Funde konnten 
auch dendrochronologisch datiert werden. Nach diesen Untersuchungen sind die wesentlichen von Eva Križanova und Vojtech Fifik (zusammen mit Mária Spološníkova) angestellten Interpretationen - was die Datierung der ältesten Bauphase anbelangt - fraglich. Die Fundsituation in Sondierschnitt 09 (Abb. 15) und in der Fundsituation 03 (Abb. 16) belegen, dass die unbearbeiteten Teile der Fenstersteinrahmen tief vom charakteristischen, homogenen Mauerwerk umschlossen werden, was darauf hindeutet, dass sie zu dem Zeitpunkt, als der Turm gebaut wurde, und keinesfalls erst nachträglich, gesetzt wurden. Auch die Putzschichten gehen um die Steinfensterrahmen herum fließend in den Lagerfugenmörtel über. In Sondierschnitt 13 (Abb. 17) ist sogar ein unbeschädigter Armierungsholzbalken im Lagerfugenmörtel unter der Fensterbank des mit einer gotischen Profilierung ausgestatteten Fensters erhalten geblieben, der per Dendroanalyse in die Zeit nach 1553 datiert wurde (Kyncl 2016). Durch einen an mehreren Höhenniveaus des Turms gemachten Vergleich der Lagerfugenmörtel - einschließlich des vorbehaltlos als rennaissancezeitlich angesehenen Teils mit dem entfernten Hohlkehlsims und den Sgraffiti - sind wir zu dem Schluss gekommen, dass es sich dabei jeweils um eine Modifizierung desselben Bindemittels gehandelt hat (Abb. 18; Krcho 2015, 9-12). Wenn wir also den oberen Teil des Turms mit dem Hohlkehlsims und den Sgraffiti als renaissancezeitlich ansehen, dann müssen wir die ganze Baumasse des Turms als renaissancezeitlich betrachten. Die hier aufgeführten Überlegungen werden auch durch eine zweite dendrochronologische Datierung eines Fundes gestützt, und zwar des Tannenbalkens des Gerüsts auf dem Höhenniveau des südlichen, seiner Form nach ebenfalls gotischen Schallfensters. In diesem Fall ist es sogar gelungen, das Fällungsjahr in die Jahreswende 1627-1628 zu datieren (Kyncl 2016).

Bei einer im Jahr 2006 auf dem Marktplatz durchgeführten archäologischen Grabung wurde eine Sonde (10/06) direkt an der Westwand des Turms gelegt. Mit einem Sondierschnitt gelang es, das Fundamentmauerwerk des Turms in der ganzen Tiefe des Fundaments freizulegen und gleichzeitig die ganze Stratigraphie der Schichten zu erfassen, die direkten Kontakt mit dem Mauerwerk des Turms haben. Die Untersuchung hat ergeben, dass die hochmittelalterlichen Schichten 8, 10 und 13 noch vor der Errichtung des Turms entstanden waren. Umgekehrt war Schicht 16 - die Steinpflasterung im Außenbereich - in der Stratigraphie des nördlichen Profils von Sondierschnitt 10/06 die erste Schicht, die mit Sicherheit erst nach dem Bau des Turms entstand. Sie setzte genau auf der Schnittstelle von Fundament und Oberfundament auf, an einer Stelle hat sie auch einen Fundamentabsatz leicht überdeckt (Abb. 10). Da Schicht 15 lediglich aus einem reinen Sandbett für die Pflasterung bestand, ist Schicht 14 für die Datierung von Schlüsselbedeutung. Für eine zeitliche Einordnung ihrer Entstehung kann mit keiner älteren Datierung als der zweiten Hälfte des 16. Jahrhunderts gearbeitet werden. Die Datierung ihrer Entstehung wird so, wie sie die Ergebnisse der jüngsten bauhistorischen Untersuchung präsentieren (Krcho 2015), mehr oder weniger auch dadurch gestützt, wie die bereits mit dem errichteten Turm zusammenhängende Pflasterung im Außenbereich angeschlossen hat.

Der Urban-Turm wurde in acht Bauphasen errichtet (Abb. 19). Ihr ältester Teil wurde einschließlich der Schallfenster mit den gotischen Formen im dritten Stockwerk in einer einzigen Bauphase - in der ersten - im Jahr 1628, bzw. 1629 unter der Leitung des Architekten Martin Lindtner für die Urban-Glocke errichtet, für die es bis dahin keinen Ort gegeben hatte, sie aufzuhängen. Eine solche Datierung ermöglichen auch die schriftlichen Quellen, und die Ergebnisse der in der unmittelbaren Umgebung des Turms durchgeführten archäologischen Grabung stehen ebenfalls in keinem Widerspruch zu diesem Schluss. Alles, was vom Turm heute zu sehen ist, wurde frühestens im Jahr 1628, bzw. 1629 errichtet.

Der vorliegende Beitrag ist im Rahmen des Projektes 1/0727/17 der Wissenschaftsagentur VEGA entstanden.

Dr. Ing. arch. Ján Krcho, PhD., Katedra teórie a dejín umenia Fakulty umení Technickej univerzity v Košiciach, Watsonova 4, SK 04200 Košice, Slovenská republika,jan.krcho@tuke.sk

Mgr. Rastislav Rusnák, PhD., Katedra teórie a dejín umenia Fakulty umení Technickej univerzity v Košiciach, Watsonova 4, SK 04200 Košice, Slovenská republika, rastislav.rusnak@hotmail.sk 
